Portland State University

PDXScholar

$1-1-2012$

\title{
Instant Canons: Film Festivals, Film Criticism, and the Internet in the Early Twenty-First Century
}

Morgen Ruff

Portland State University

Follow this and additional works at: https://pdxscholar.library.pdx.edu/honorstheses

Let us know how access to this document benefits you.

\section{Recommended Citation}

Ruff, Morgen, "Instant Canons: Film Festivals, Film Criticism, and the Internet in the Early Twenty-First Century" (2012). University Honors Theses. Paper 13.

https://doi.org/10.15760/honors.13

This Thesis is brought to you for free and open access. It has been accepted for inclusion in University Honors Theses by an authorized administrator of PDXScholar. Please contact us if we can make this document more accessible: pdxscholar@pdx.edu. 


\title{
INSTANT CANONS: \\ FILM FESTIVALS, FILM CRITICISM, AND THE INTERNET IN THE EARLY TWENTY- FIRST CENTURY
}

by

Morgen Ruff

\begin{abstract}
A thesis submitted in partial fulfillment of the requirements for the Bachelor of Arts degree in Film Studies in the School of Fine and Performing Arts of Portland State University
\end{abstract}

May 2012

Thesis Supervisor: Professor Mark Berrettini 
Above and beyond the loss of material, the living history of cinema, like any other history, is riddled with memory losses which, while aggravated and accelerated by the physical extinction of so many works, also encompass vast amounts of significant achievement extant but little seen or heard of. What were revered classics for one generation of filmgoers slip into oblivion for the next, the result of everything from changes in taste to trends in the economics of theatrical and non-theatrical distribution to the withering of repertory cinema -- conditions all symbiotically linked to a host of other factors as well.

- John Gianvito ${ }^{1}$

I think that posting the films online is already the greatest film festival possible; it is enough. What is the use of another film festival?

- Ai Weiwei ${ }^{2}$

What the Hoberman Affair shows is that we are equally afraid that, with the disappearance of print journalism, film criticism threatens to become a Matrix-like simulation of what criticism once was. So what can film critics do when the medium's ontological basis is changing in front of their eyes-when their own reality is threatened.

- Mark Peranson ${ }^{3}$

${ }^{1}$ John Gianvito, “Remembrance of Films Lost," Film Quarterly 53, no. 2 (Winter 1999-2000): 39.

2 J.P. Sniadecki, "Documentary is Just One of My Tools: The Cinematic Activism of Ai Weiwei," interview with Weiwei, Cinema Scope 49 (2012), 33.

${ }^{3}$ Mark Peranson, "Film Criticism After Film Criticism," Cinema Scope 50 (2012), x. 


\section{Introduction}

World film culture today is by-and-large dominated by two competing systems of production, distribution, and exhibition: the Hollywood system and the international film festival system. Of course, there are other, alternative systems, but for the most part they are relegated to the periphery. The film festival calendar (for feature films) is dominated by a handful of events: in Europe, at Cannes, Berlin, Venice, Rotterdam, London, Thessaloniki, Moscow, Karlovy Vary, and Locarno; in Asia, at Hong Kong, Singapore, Pusan, Tokyo, and Shanghai; in Africa, at Cairo and Ouagadougou; in Oceana, at Melbourne and Sydney; in South America, at Buenos Aires, Mar Del Plata, and São Paolo; finally, in North America at Toronto, New York, Sundance, Telluride, Montreal, Austin, San Francisco, and Chicago. Premiere-heavy festivals like Cannes, Berlin, and Sundance tend to garner the most media coverage, as the newness of the year's crop of films tends to grab most of the headlines (also key is the anticipatory aspect of these, where the latest films by renowned directors are speculated upon in a seemingly endless cycle).

Festivals are key to film culture for several reasons. First, they constitute an alternative distribution network that allows relatively more films — and thus more styles of film — to circulate and thus be seen by audiences worldwide — and audiences would not see many of these films otherwise. Second, the bigger festivals often offer financial support to filmmakers in under-privileged areas of the world, increasing the number of voices able to tell a story. Third, festivals offer their host cities revenue from tourism, as many of the bigger festivals draw audiences from around the globe or at least the nearby region. Scholars have analyzed all of these aspects to a certain degree; in addition, festival organizers and critics are highly aware of these events' place within both the world film system and the local and national economy. Furthermore, the compressed temporal element of most film festivals - in that they take place in 
as little as a weekend or as long as a month — adds yet another layer to any analysis of either the event or the vast apparatus of production surrounding it (filmmaking, criticism, etc.).

In this thesis, I first examine the general scholarly discourse surrounding film festivals as both cultural phenomenon and commercial system. As I will show, the discourse is relatively fractured in that the amount of film festival scholarship has grown very quickly in the past 20 years; in addition, much like the discipline of film studies on the whole, there are a number of issues to attend to and an even greater number of approaches to take when addressing them. In the second half of the thesis, I trace the online critical discourse surrounding two "festival films": Apichatpong Weerasethakul's Uncle Boonmee Who Can Recall His Past Lives (2010) and Béla Tarr's The Turin Horse (2011). Critics have widely praised both films, but as I will show, the discussion online has tended to focus on a handful of very specific aspects of the films and their festival lives. This, along with the general state of distribution and exhibition in the U.S., has in effect shorted the theatrical life of the films. In addition, I argue, through two theories of film canonization, that these films have an ideological edge which to date critics have not engaged with, and which demands further scholarly study in order to do the films' complexity justice.

\section{Literature Review}

\section{Introduction}

Within the discipline of film studies, the general focus of scholarship has historically tended toward analyses and histories of specific films, audiences, genres, national movements, directors, and the exhibition context of films. Film festivals, despite occupying a central role in world film culture since the first festival at Venice in 1938, have been historically understudied. However, the past two decades have seen a blossoming in scholarship particularly focused on the cultural phenomena of film festivals. Since festivals occupy a key place in world film culture - 
in that as a whole they represent a kind of clearinghouse where very diverse audiences can see all kinds of film not normally seen in 'regular' exhibition contexts — scholars, mostly European, have recently analyzed their various facets. These include the interconnectedness of festivals globally, issues of festival competitions and programming more generally, national and generic film movements as they relate to festivals (which includes festivals specifically geared towards individual nations, regions, and movements), business and marketing, the socio-economic makeup of particular festivals, issues relating to audiences, and the role of the media within the global festival landscape. Other broad trends, most notably case studies of particular festivals, which serve to provide history and context for each, have begun to spring up in recent years. However, for the scope of this thesis I must focus on the major issues in festival studies that have been covered by several scholars, as the discourse is increasingly fragmentary due to its compressed temporality and necessarily multi-faceted constitution.

\section{The Circuit}

A key tendency within film festival scholarship has been to treat the broad mass of film festivals worldwide as an interconnected network or circuit, through which films gain cultural capital via screenings and awards and subsequently traverse the globe to be seen by audiences in a wide variety of contexts (at both festivals/events and at regular theatrical screenings). Although this notion of the circuit has begun to be directly challenged or at least gently called into question, it remains dominant within film festival studies. Indeed, it is difficult to see mega-festivals like Cannes and Berlin anything more than tangentially connected with, as examples, the many queer or African festivals worldwide (instead, it seems more helpful to see a series of circuits or networks, based on broad groupings, although this is problematic as well). 
The first work explicitly dealing with the idea of a film festival circuit — and coincidentally one of the first scholarly articles on festivals as a whole — appeared in 1994, as Bill Nichols addressed the recent 'arrival' of Iranian national cinema on the festival circuit (at the 1992 Toronto International Film Festival, specifically). ${ }^{4}$ Here Nichols addresses several concerns that crop up with the introduction of a new national cinema into a global context, foremost of which is the dialectical relationship between universality of appeal and the film's local specificity (both of which are tied up in critical interpretation of films and depend heavily on the particular critic's cultural placement). For Nichols, as each film makes its way through various contexts, it is interpreted differently, although through this process it retains a 'hidden' meaning to viewers in its native context.

In a key chapter of his book European Cinema Face to Face with Hollywood, Thomas Elsaesser also addresses the notion of a circuit, specifically the way it dominates European film distribution in the twenty-first century. ${ }^{5}$ For Elsaesser, this leads directly to sweeping changes in the way that films are produced, exhibited, received, and appreciated; in essence, festivals sort through and classify the year's cinematic production, which is then further disseminated to arthouse theaters and other exhibition sites. From this comes a hierarchy of festivals (which have notably been grouped by FIAPF into ' $A$ ' and ' $B$ ' festivals), where leading events like Berlin, Cannes, and Venice set the tone for the festival season; moreover, those ' $\mathrm{B}$ ' festivals that follow often shape their programming around what has shown (successfully) at 'A' festivals. The circuit for Elsaesser also acts as a counter-system to the Hollywood production and distribution model,

\footnotetext{
${ }^{4}$ Bill Nichols, "Discovering Form, Inferring Meaning," Film Quarterly 47, no. 3 (Spring 1994): 16-30.

5 Thomas Elsaesser, "Film Festivals Networks: The New Topographies of Cinema in Europe," in European Cinema Face to Face with Hollywood (Amsterdam: Amsterdam University Press, 2005), 82-107.
} 
where filmmaking is centralized and global distribution dominance has been in place since the heyday of the classical Hollywood era.

Following directly from — and heavily influenced by — Elsaesser's work with regard to the interconnectivity of the film festival network, in Film Festivals: From European Geopolitics to Global Cinephilia, Marijke de Valck addresses several aspects of the way the network operates, referring to each festival as a "nodal point" in a larger system, which is made up solely of the nodes - no one event is wholly central to the network. ${ }^{6}$ She ties her idea of the network together with four case studies - of the key international festivals in Berlin, Rotterdam, Cannes, and Venice — that allow her to illustrate the interconnectedness of these major events in the film calendar. In each case, de Valck examines a different aspect of the film festival apparatus: in the case of Berlin, the historical development of festivals; in the case of Rotterdam, the intersection between programming and audiences; in the case of Cannes, the film festival marketplace and the economic framework of festivals; finally, in the case of Venice, the media element of festivals. De Valck also brings in the actor-network theory of Bruno Latour to discuss "sites of passage," which she labels festivals in terms of their ability to confer cultural capital onto films that in turn are sold for worldwide distribution on the strength of their performance as precisely those festivals. This she calls "value addition," which comes via awards and competition screenings; the idea inherently suggests an interconnectivity among festivals, since there would be no functional worth to that which is added if the film did not receive subsequent screenings elsewhere. De Valck also pinpoints a strong relationship between the local and the global within the network, as there are hundreds of small local festivals that program and exhibit films that have shown at the powerhouse festivals through the year.

\footnotetext{
${ }^{6}$ Marijke de Valck, Film Festivals: From European Geopolitics to Global Cinephilia (Amsterdam: Amsterdam University Press, 2007).
} 
Also following Elsaeser's work, Owen Evans questions the dominance of the Cannes Film Festival within a European context through a comparison with the Berlin and Karlovy Vary festivals. ${ }^{7}$ Evans notes that Elsaesser's work tended toward the homogenization of European events while showing that Cannes is far less locally and nationally specific than other major festivals (in that Berlin and Karlovy Vary have sidebars dedicated to their national cinemas, etc.). Evans uses a post-colonial theoretical framework, largely drawn from the work of Edward Said and Homi Bhabha, to illuminate the ways in which the festival universe is in fact at once subservient to Hollywood while at the same time creates hierarchies within its own structure as a circuit (e.g. major festivals shape the programming of smaller festivals, and so on). One of his major points in terms of the metaphor of post-colonialism is the question of who is allowed to attend festivals: Cannes is relegated to industry professionals only (the only festival in the world set up like this), whereas Berlin and Karlovy Vary rely heavily on general audience participation. Finally, Evans notes a trend in Hollywood of quickly remaking successful European and Asian films (e.g. Girl With the Dragon Tattoo, Let the Right One In, et al.), which has in recent years simultaneously been met with Cannes' own return to edgier fare in its main competition, which Evans sees as doubly promising signs for the future of art-house cinema.

Where Elsaesser and de Valck both focus on the interconnectivity of festivals and their impact on film culture at large, Ragan Rhyne in a 2009 article argues that instead of a structurally interconnected network, what ties film festivals together is their reliance on public and private subsidies — an economic framework that privileges a non-profit organizational

\footnotetext{
${ }^{7}$ Owen Evans, "Border Exhanges: The Role of the European Film Festival," Journal of Contemporary European Studies 15, no. 1 (2007), 23-33.
} 
model. ${ }^{8}$ In Rhyne's view, there is a vast apparatus surrounding film festivals that seek to proliferate the network in their own interests; meanwhile, a hierarchy of cities is formed along this circuit, all of which compete for tourist attention. In sum, Rhyne's idea of a film festival circuit revolves around the flow of capital, not necessarily around the flow of filmic artifacts as such.

Following directly from Rhyne, Dina Iordanova also throws the idea of a cohesive network into question by focusing on the idea that festivals have generally sprung up independently and slowly connected themselves to what Iordanova sees as a very loose grouping of events. ${ }^{9}$ To further this idea, she distinguishes between networks proper (which would, in theory, be standardized throughout) and the "ad-hoc" nature of putting on a film festival, where film prints and digital copies are coming from around the globe with no discernable, overarching organization. Moreover, Iordanova notes that festivals increasingly compete directly with each other (for premieres, stars, tourism capital, etc.), which goes directly against the idea of interconnectivity. Iordanova also identifies "parallel circuits" (film festivals focused on specific social issues, genres, audiences, or localities/regions), so to treat the global film festival scene as a highly structured, single mass is to simplify the questions surrounding festivals and their impact.

David Andrews, in a 2010 article on "art cinema," provides another wide view of the

\footnotetext{
${ }^{8}$ Ragan Rhyne, "Film Festival Circuits and Stakeholders," in Film Festival Yearbook 1: The Festival Circuit, edited by Dina Iordanova and Ragan Rhyne (St. Andrews: St. Andrews Film Studies, 2009), 9-22.

${ }^{9}$ Dina Iordanova, "The Film Festival Circuit," in Film Festival Yearbook 1: The Festival Circuit, edited by Dina Iordanova and Ragan Rhyne (St. Andrews: St. Andrews Film Studies, 2009), 2339.
} 
festival circuit and the films programmed within. ${ }^{10}$ His work engages directly with that of Elsaesser, in that Andrews recognizes the film festival circuit as a broad flow of cultural capital that is systematically self-sustaining. For Andrews's conception of "art cinema," the festival is a key site through which the process of event-driven ritual and textual delineation occur; those elements help to define what is and what is not considered art cinema, and thus which films do and do not have extended life beyond these fleeting events. Andrews concludes that the term "art cinema" is very useful in every arena of discourse surrounding cinema, since a marked relationship between the non-heterogeneous nature of "art cinema" (which has been posited otherwise by David Bordwell, i.e., that it is heterogeneous) and those areas does in fact exist and provides fruitful areas of further study.

Cindy Wong, in her key 2011 monograph on film festivals, provides the first truly historical picture of the circuit. ${ }^{11}$ At the time of publication, the idea of a circuit was largely entrenched in festival studies, but Wong maps the different roles that each festival or type plays in the larger picture (e.g. Cannes, Venice, and Berlin as festivals of premieres, New York as a yearly sampler of hot international festival properties, or Sundance as the foremost promoter of independent American film). She concludes that the hegemonic presence of Cannes, Venice, Berlin, and similar mega-festivals have continued to serve as the unofficial centers of the circuit, smaller festivals with differing concerns and foci have continued to spring up worldwide — and thus laying the foundation for new, 'parallel' circuits, an argument that clearly follows the discourse to this point.

${ }^{10}$ David Andrews, "Art Cinema as Institution, Redux: Art Houses, Film Festivals, and Film Studies," Scope: An Online Journal of Film \& TV Studies 18 (2010).

${ }^{11}$ Cindy Wong, Film Festivals: Culture, People, and Power on the Global Screen (New Brunswick, NJ: Rutgers University Press, 2011), 37-64. 


\section{Competitions/Programming}

Scholars have discussed film festival competitions and programming practices in great detail in the last several years, as competitions have generally been identified as bestowing cultural capital or "value addition" 12 upon films that enable them to move along the circuit (since they have been deemed 'worthy' of broader exposure). Competitions, of course, have a major ideological component, since the juries assigned to give awards are, by-and-large, made up of filmmakers, actors/actresses, producers, and others directly involved in the filmmaking process, but very rarely are critics, programmers, and others involved in the extra-textual side of the film industry asked to sit on juries. In fact, juries, in their own way, are "value added" to a festival, since they up the star power on the whole while providing legitimacy to the proceedings. Programming practices, on the other hand, are performed behind closed doors, with little to no questioning by the press - and here is arguably the larger ideological problem in that what does and does not "make it" into a festival's lineup can, and often does, run along preexisting societal divisions (see, for example, the relative lack of African films at the major European and North American festivals).

Liz Czach approaches the topic of programming via a discussion of its roles in the creation of a national cinema, in particular Canadian cinema at the Toronto International Film Festival ${ }^{13}$ For Czach, a phenomenon she terms "critical capital" — which includes adding prestige to a film the knowledge of those festivals at which it has screened, which critics reviewed it, and general audience response — is the key mechanism through which films enter

\footnotetext{
${ }^{12}$ This is the terminology Marijke De Valck uses — mostly relating to film criticism — in discussing the apparatus surrounding films at festivals, especially in her chapter on the Venice Film Festival. In De Valck, Film Festivals, 122-161.

${ }^{13}$ Liz Czach, "Film Festivals, Programming, and the Building of a National Cinema," The Moving Image 4, no. 1 (Spring 2004): 76-88.
} 
into the canon of acceptance. However, she is careful to note that film festival-related cache is just one of many factors playing into canonization. Of course, without programmers inserting films into festival lineups, critical capital would lack applicability. For Czach, then, the programmer plays a very powerful role in the film festival circuit — as tastemaker and gatekeeper, both of which have highly politicized dimensions.

In a recent article, Marijke De Valck and Mimi Soeteman examine the inner workings of film festival competition juries at the International Documentary Festival Amsterdam (IDFA), which is generally known as the key documentary event of the year (analogous to Cannes and feature-length, fictional narrative cinema). ${ }^{14}$ Through an examination of a twenty-year period of juries at IDFA, De Valck and Soeteman make three central claims about award-giving at competition festivals: that there are no set criteria (i.e. a framework) by which to judge films, that the festival "primes" the jury through the selection of films, and that jury deliberations are generally geared toward subjectivity and cultural preference.

\section{Specific/Generic/National Cinemas}

Directly related to competition and programming issues, the rise of certain cinematic new waves from particular nations has, within the last 20 or so years, generally started at film festivals; thus, it is necessary to study the ways in which national cinemas are programmed, reviewed, and received at festivals worldwide, and how films with local and regional specificity are consumed outside of their originating context.

Lucy Mazdon writes about the furthering of a French national cinema at the Cannes Film Festival in a piece that shows parallels with Czach's work on Canadian cinema in that in both

\footnotetext{
${ }^{14}$ Marijke De Valck and Mimi Soeteman, “'And the Winner is...': What Happens Behind the Scenes of Film Festival Competitions," International Journal of Cultural Studies 13 (2010): 290307.
} 
cases a major festival can be seen as a site of national promotion. ${ }^{15}$ Mazdon's conclusions about French cinema at Cannes illustrate the complex nature of film festivals today, in that French cinema specifically must promote national agendas while operating in a transnational framework — as a great deal of international co-productions originate or have significant financing from French sources.

While Mazdon and Czach focus on the representation and creation of a national cinema within the context of its unofficial 'home' festival (e.g. Canadian cinema at Toronto, French cinema at Cannes), Azadeh Farahmand has recently examined Iranian cinema across the wider film festival circuit. ${ }^{16}$ Genre, for Farahmand, takes shape when select information is passed down from the privileged few of the circuit (e.g. programmers, producers, film agents) to viewers and critics, which coalesces into a collective interpretation. He also identifies a key trend in film criticism surrounding festivals - that filmmakers from 'festival darling' nations (e.g. Iran in the 90s, Romania in the last decade) have shaped and styled their films in order to conform to a broader "festival style" of film that is increasingly likely to garner acclaim (this, quite possibly, is where the term "festival film" comes from, but it is difficult to pinpoint where that term begins and ends - i.e., what its limits are).

Ma Ran has also analyzed the reception of a specific national cinema on the broader circuit — in this case, one with a growing international presence: 'Urban Generation' Chinese

\footnotetext{
${ }^{15}$ Lucy Mazdon, "Transnational 'French' Cinema: The Cannes Film Festival," Modern \& Contemporary France 15, no. 1 (February 2007), 9-20.

${ }^{16}$ Azadeh Farahmand, "Disentangling the International Festival Circuit: Genre and Iranian Cinema," in Global Art Cinema: New Theories and Histories, edited by Rosalind Galt and Karl Schoonover (Oxford: Oxford University Press, 2010): 263-281. Also of note here is Bill Nichols' work (1994) on critical and audience reception of Iranian film at the 1992 Toronto International Film Festival.
} 
cinema. ${ }^{17}$ Ran proceeds through a three-fold argument: first, a look at the film festival as a new global industry with ideological and political elements that largely play out via programming practices; second, the circulation of Urban Generation Chinese films on the circuit and how they operate on the margins; third, the 'festival film' as a unique mode of filmmaking, by which filmmakers tailor style, content, and timing to various festivals. Ran's conclusions illustrate the film festival circuit as central to new Chinese filmmaking in that it is, in many cases, the major avenue for young filmmakers to engage with this new global visual economy.

\section{Business Aspects}

The commercial side of festivals, while implicitly addressed in nearly every study in this area, has seldom seen sustained attention paid to it, possibly due to the perceived separation between art (as is normally the mode of filmmaking at festivals worldwide) and commerce (the domain of Hollywood and other national industrial contexts). Often, "festival films" are branded with the "art house" moniker when making their way stateside as a way of separating them from mainstream releases (of course, it does not help that, if these films receive a U.S. release at all, it is often only in New York and Los Angeles). Several scholars note the presence of major Hollywood films at international film festivals, where they are often premiered for critics (this phenomenon most often happens at Cannes, Berlin, and Venice - in the case of Cannes, the films are sometimes in competition, as was Terence Malick's The Tree of Life at the 2011 edition).

Robert Sklar, in a 1996 report from Cannes, argues that the festival is the ideal place for world cinema to reassert itself in the face of Hollywood hegemony, in that it is the premier venue in which cinema professionals can see both art house and big-budget films in the same place at

\footnotetext{
${ }^{17}$ Ma Ran, "Rethinking Festival Film: Urban Generation Chinese Cinema on the Film Festival Circuit," in Film Festival Yearbook 1, 116-135.
} 
the same time. ${ }^{18}$ The cultural significance of Cannes is thus as a proving ground — both artistically and economically — for under represented or under-shown national cinemas. Sklar notes that one problem associated with this idea is that Hollywood does not just send any film to Cannes: American products usually include works by the preeminent auteurs (e.g. Woody Allen, Spike Lee, Martin Scorsese, et al) and generally do not include blockbusters, which are reserved for premiere in American theaters so as to avoid negative reviews by international critics ahead of their release.

Julian Stringer, who addresses the city as a site for film festivals to exist, argues that cities now form the key nodal points of the global network of film festivals, not national film industries, as was the case through the mid-twentieth century. ${ }^{19}$ Cities must cultivate a number of identities to stay competitive in the global marketplace, and thus film festivals become a key attraction (particularly at certain times of year, as film festivals are often programmed during 'down' times of tourism). Stringer also offers key terminological differentiations with regard to the film festival circuit: he variously offers it as perceived to be "open" yet closely linked, closed and immune to outside manipulations, and as metaphorical for geographical imbalance regarding film production (e.g. film festivals in Africa have not led to increased opportunities for filmmaking by Africans). Stringer's evidence includes several scholarly accounts of the film festival phenomenon, including articles focused on Chinese film production and transnationalism, the early years of the Berlinale, and the Pusan International Film Festival in Korea.

\footnotetext{
${ }^{18}$ Robert Sklar, "Beyond Hoopla: The Cannes Film Festival and Cultural Significance," Cineaste 22, no. 3 (December 1996), 18-20.

${ }^{19}$ Julian Stringer, "Global Cities and the International Film Festival Economy," in Cinema and the City: Film and Urban Societies in a Global Context, edited by Mark Shiel and Tony Fitzmaurice, (Oxford: Blackwell, 2001), 134-144.
} 
Marijke De Valck addresses the business aspects of festivals largely through the discussion of marketing, which is primarily seen through the creation of a "festival image" through which each festival on the global circuit differentiates themselves from their perceived competitors. ${ }^{20}$ De Valck's concept of "value addition" comes to the fore with marketing, as precisely those things that are added (e.g. the appearance of stars, awards, and gala events) are what generate the most opportunities for the festival to set itself apart. ${ }^{21}$ Examples of festivals that have unique traits to market include the Midnight Sun Festival in Sodankylä, Finland, which takes place during the period of the year where the sun never sets, and the Sarajevo Film Festival in former Yugoslavia, which was founded during the 1995 bombings of the city, and is thus politically charged through its defiant beginnings. ${ }^{22}$ Both of these examples contribute to the idea of the "festival image," which is continued in the major festivals of Cannes, Berlin, Venice, and Rotterdam in very subtle and historically important ways.

Film festival organization is a key consideration when assessing the place of a festival within the global picture; Mark Peranson, writing in the third volume of the Dekalog series, notes two models of film festival organization: those based primarily in the business sphere, and those focused on audience experience first and foremost. ${ }^{23}$ Peranson lays out the various organizational tendencies of each type of festival - for example, budget differences, staff size, the presence of competitions and film funds, and studio involvement — which are, on the business side, epitomized in Cannes, Berlin, Venice, Toronto, and Pusan, while on the audience side, prime examples include Vancouver, Buenos Aires, Vienna, Seattle, and many others.

\footnotetext{
${ }^{20}$ De Valck, Film Festivals, 73.

${ }^{21}$ Ibid., 125-126.

22 Ibid., 137

${ }^{23}$ Mark Peranson, "First You Get the Power, then You Get the Money: Two Models of Film Festivals," in Dekalog 3: On Film Festivals, edited by Richard Porton (London and New York: Wallflower Press, 2009), 23-37.
} 
Despite laying out this broad, binary opposition within the festival world, Peranson notes that, for the most part, the majority of festivals operate somewhere in the middle and include characteristics of each type, as particular needs at each locality sometimes necessitate different organizational approaches (i.e. no two festivals are exactly alike). One of Peranson's major contentions is that "premiere-heavy festivals such as Berlin or Sundance do just as much harm as good to the world of cinema," 24 in that those types of festivals nurture "crossover' films which seek to replicate the success of previous festival hits (e.g. the case of Rushmore clones).

For Cindy Wong, the business of film festivals has more to do with official film markets (industry gatherings at festivals where films are bought and sold for distribution worldwide): "with the importance of global markets today, no major festival wants to do without one, but each must grapple with those that already exist." 25 Wong notes that nearly every major film festival as well as festivals in major metropolises host film markets as a way of attracting industry personnel, new talent, and hordes of media to their city, which in turn fuels the flow of tourism dollars and the increase of cultural capital for new global players (e.g. Dubai, which started its film market in 2007). Wong notes that the markets often play a backseat role to festival screenings and competitions, which are "the more public faces of the festivals," 26 and often those open to the public (markets are, generally speaking, industry-only events).

\section{Anthropological Views}

Since its introduction into academia in the 1960s, film studies has seen a number of influential studies written on spectatorship and audiences, although rarely have scholars addressed event-driven issues, instead often opting for wide-ranging historical analyses focused

\footnotetext{
${ }^{24}$ Ibid., 33.

${ }^{25}$ Wong, Film Festivals, 139.

${ }^{26}$ Ibid., 141.
} 
on particular periods or genres. ${ }^{27}$ Practically no attention has been paid to film festivals as sites of spectatorship, despite traditionally large crowds and sold-out screenings. However, in recent years, two articles have appeared from sociologists examining the Utah's Sundance Film Festival.

Nancy Lutkehaus examines the 1995 edition of Sundance and gives a broad overview of the documentary films showing that year while exploring general thoughts about the organization and social aspects of the festival. ${ }^{28}$ Part of her work posits Sundance as a modern day world's fair, a mirror of those major expositions of the late-nineteenth and early-twentieth centuries. Although she notes several differences between film festivals and world's fairs, the differences Lutkehaus pinpoints include the evocation of a sense of community, expositions of new filmmaking forms to audiences, and the promotion of ideological goals. She explores each of these issues through discussions of various sidebars within the Sundance festival — including Native American cinema, new Canadian films, and others. The conclusions Lutkehaus draws are in line with many views on Sundance during the mid-1990s: that while Hollywood had an increasingly strong presence at the festival, it remained a key event on the yearly North American festival calendar for adventurous moviegoers.

In a 1997 piece, Daniel Dayan, trained as an anthropologist, looks at that year's edition of the Sundance Film Festival, focusing on the ways in which there are various performances by

${ }^{27}$ See, for example, Miriam Hansen, Babel and Babylon: Spectatorship in American Silent Film (Cambridge, MA: Harvard University Press, 1994) and Richard Allen, Projecting Illusion: Film Spectatorship and the Impression of Reality (Cambridge and New York: Cambridge University Press: 1995), among others.

${ }^{28}$ Nancy C. Lutkehaus, "The Sundance Film Festival January 19-29, 1995: Preliminary Notes Towards an Ethnography of a Film Festival," Visual Anthropology Review 11, no. 2 (Fall 1995), 121-129. 
each group present at the festival. ${ }^{29} \mathrm{He}$ analyzes the festival itself (i.e., its structures and its integration within the location where it is held), journalists (the specific language of festival reports, the self-preserving loop of their work), films (in relation to genre and Mikhail Bakhtin's notion of modularity within the same language - languages of class, race, profession, et al.), sales (the ways that transactions are carried out and their importance to the overall air of the festival), filmmakers (legitimation in terms of their families and identities — sexual and other), and audiences (pilgrimage, witnessing of the sacred). Dayan's conclusions about festivals through the lens of the 1997 Sundance Film Festival is informed by Roland Barthes' work on the fashion industry, in that Dayan notes that the vast amount of writing that festivals produce say more about festivals than focusing solely on the apparatus of the festival itself. Dayan notes a "double festival": one of the films themselves, and one of the "written festival," which exists as Park City itself. Dayan's work recalls a follower of Barthes, the film theorist Christian Metz, who in his early work made a distinction between the text of film itself and the vast apparatus surrounding it (i.e. production, distribution, exhibition, audience, and press).

Liz Czach discusses the role of cinephilia from its beginnings during the era before home video and the Internet up through the contemporary situation of cinephilia's rediscovery as film festivals. ${ }^{30}$ She focuses on three festivals - Sundance, Toronto, and Cannes - through which she illustrates the various responses to the perceived death of cinephilia and theater-going (Susan Sontag's "Death of Cinema" is a major theoretical touchstone here). Also noteworthy is Czach's discussion of the act of watching a film at a festival, where the experience is simultaneously

${ }^{29}$ Daniel Dayan, "Looking for Sundance: The Social Construction of a Film Festival," in Moving Images, Culture, and the Mind, edited by Ib Bondebjerg (Luton: University of Luton Press, 2000), 43-52.

${ }^{30}$ Liz Czach, "Cinephilia, Stars, and Film Festivals," Cinema Journal 49, no. 2 (Winter 2010): 139-145. 
shared with a large audience and idiosyncratically private in terms of personal response to a film. Czach identifies the modern film festival as the last refuge for cinephilia, but argues that festivals are increasingly star- and celebrity-driven affairs in which glamour and fame take center stage, removing focus from the films themselves (many of which can only ever be seen in a festival context). Czach concludes that star-driven festivals with explicit economic agendas threaten the resurgence of cinephilia on the whole. The cinephilic encounter with a film is also largely relegated to after-the-fact festival reportage in magazines, which only serve that segment of the film-going population (although Czach notes that internet-based critics, a new generation, are on the rise and thus so is rapid-fire reaction and opinion-sharing about festival films).

\section{Festivals and the Media}

One of the most important communities at any festival is the popular media, who disseminate opinion of films for both local and remote audiences (in fact, much is written about the major European festivals specifically for target audiences of cinephiles in the U.S. and Canada hoping for quality festival films to make it to our shores). While programming choices and jury deliberations may (arguably) have the strongest ideological impact and gatekeeping function at festivals, critical discourse by way of reviews and festival overviews can indeed help create and subsequently define a film's commercial lifespan beyond its initial festival premiere.

Janet Harbord directly addresses issues of press reception, which for her is the direct mediator between a festival and the public, in that the journalist's accounts of first-hand experience at festivals operates in surrogate for the reader unable to attend the event. ${ }^{31}$ While personal experience is usually front-and-center in press coverage of festivals, Harbord notes that "significantly less attention is offered to the marketing dimension of the festival, the sale of

31 Janet Harbord, "Film Festivals: Media Events and Spaces of Flow," chapter 3 in Film Cultures (London: Sage Publications, 2002), 59-75. 
distribution rights to various companies. These stories of economic exchange also determine the future circulation of films, and it is perhaps partly in a disavowal of the afterlife of the film that such information is only thinly represented." 32 She further notes that any critical discourse surrounding film within the site of a festival will undoubtedly harken back to old debates about art versus commerce, in that "diverse and competing forces...permeate the festival site.",33

Marijke De Valck discusses media and its role at the Venice Film Festival (Viennale), particularly the ways in which there exists a differentiation between "quality" press, who tend to report on serious films with a high degree of accuracy, and the general media, who tend to report on gala events and the appearance of stars. ${ }^{34}$ A major point of discussion in De Valck's work, which comes from the high/low differentiation, is the issue of press accreditation: "segregation in the organization of festivals is normally carried out by systems of accreditation. Not everybody can access film festivals equally." 35 She also offers up some broad categorizations about the preoccupations of critics at festivals, which include a focus on major competitions, awards, new talent, new genres, new waves, current and global topics, and finally an interest in their own country's showing at the festival (this is more applicable to large, premiere-oriented festivals like Cannes, Berlin, and Venice).

While the prevailing trend of festival films is to operate in opposition to Hollywood cinema, Cindy Wong argues, “festival-oriented cinema must appeal to other kinds of audiences: the festival cinephiles, the festival professionals, and the festival critical apparatus. ${ }^{36}$ In a discussion of the way critical discourse operates at the Cannes Film Festival, Wong examines the

\footnotetext{
32 Ibid., 69.

33 Ibid., 74.

${ }^{34}$ De Valck, Film Festivals, 124-125.

35 Ibid., 141.

${ }^{36}$ Wong, Film Festivals, 70.
} 
critical reception of Michelangelo Antonioni's L'Avventura (1960) and Abbas Kiarostami's

Taste of Cherry (1997), noting the relative quickness by which each film had particular traits and qualities assigned to it by the critical community - in the former's case, the general furor about L'Avventura's oblique style and "incoherent" narrative, and in the latter's case, the nonWesternness of the director, as the makeup of critics at Cannes is almost exclusively Western in origin. ${ }^{37}$ Wong's conclusions about the critical apparatus at festivals largely aligns with De Valck's general conclusions (particularly about the phenomenon of "value addition"), although she makes note of the key difference between popular critics, who must offer rapid-fire reactions to films in order to meet deadlines and stay timely, and scholars of film, who generally have much more time to ponder films, perform background research, and thus create nuanced positions on films that otherwise revolve through the door or world cinema.

While by no means has this literature review been — or pretended to be - exhaustive, I have looked at several of the key examples of recent scholarship in the field of film festival studies. Specifically, I have tried to give a broad overview of the general trends of the field, but naturally such a fragmentary and still emerging discourse proves tough to adequately encapsulate in the limited space available to a project like this thesis. The specific examples I have chosen represent foundational works in the field, which scholars continue to build upon. They also represent new voices, whose numbers are increasing exponentially as the Film Festival Yearbook series continues into its fourth year in $2012 .{ }^{38}$

\footnotetext{
${ }^{37}$ Ibid., 112-122.

${ }^{38}$ After volume one, which I have given some attention to here, volumes two, three, and four respectively deal with "imagined communities" (in Benedict Anderson's sense), East Asia, and activism.
} 


\section{The Crisis in Film Criticism, and Why the Internet is Important}

The crisis of print journalism, particularly in American newspapers, has been well documented over the last several years. This crisis has hit film criticism quite hard, with several major film critics being laid off from their regular posts recently — including David Ansen of Newsweek and both Nathan Lee and J. Hoberman of The Village Voice among others nationwide. While this trend has certainly affected the exposure of lesser-known films (e.g. those that primarily play at festivals) to a wider audience, it has also driven film culture to shift online to a much greater degree. This shift has not only enabled a new set of voices to come to the fore, but it has also enabled completely new forms of film criticism.

The Internet as clearinghouse of public and critical opinion, especially with regard to film culture, is most clearly exemplified in review aggregator sites like Rotten Tomatoes and Metacritic, where those looking for critical opinions can see the average review of a substantial mixture of both "top" critics — i.e. those who write for major publications — and lesser-known bloggers and beat writers. Aggregator sites such as these threaten to make individual critical voices lost in the crowd, since with the rise of Internet-based criticism where theoretically anyone can participate, increasingly more voices are present in the first place. As Jürgen Gerhards and Mike Schäfer argue in their paper comparing traditional print media with Internetbased spheres of discussion, "search engines," a category in which aggregators can rightly be classified, "might actually silence societal debate by giving more space to established actors and institutions, to experts and to expert evaluations and views, thereby replicating pre-existing power structures online." 39 Often on review aggregators the established critics from major news outlets get top billing — so, for example, the first six reviews listed are from 'top' critics —

\footnotetext{
${ }^{39}$ Jürgen Gerhards and Mike S. Schäfer, "Is the internet a better public sphere? Comparing old and new media in the USA and Germany," New Media and Society 12, no. 1 (2010): 156.
} 
which serves to reinforce their position in the industry while relegating smaller websites and blogs to the bottom of both the page and the pecking order.

In addition to popular criticism websites dealing specifically with film, a number of semiacademic journals have appeared online in the last several years, including Senses of Cinema, Moving Image Source, Bright Lights Film Journal, Screening the Past, Rouge, and others. These kinds of repositories ostensibly seek to bridge the gap between formal academic film study and popular criticism. Former Chicago Reader critic Jonathan Rosenbaum, in a brief article on the subject says, "in short, we're living in a transitional period where enormous paradigmatic shifts should be engendering new concepts, new terms, and new kinds of analysis, evaluation, and measurement, not to mention new kinds of political and social formations, as well as new forms of etiquette. ${ }^{40}$ Rosenbaum goes on to note that, for him, this is not happening, and that the same structures that came from "old" forms of critical analysis have now simply shifted online. While this structural repetition is important to keep in mind, at the same time it is relevant to note the relative youth of Internet film culture. In recent years, several new trends have popped up; one prime example is the rise of video essays produced by critics. ${ }^{41}$

While print media has historically tended to focus on long-form reviews of individual films, criticism online splinters into two varieties. Those long-form reviews are still present but by-and-large not beholden to word count limits online as are their print counterparts. Festival round-ups, on the other hand, are increasingly popular and offer truncated but incisive insight into a number of films playing a given festival. These round-ups are commonly produced at the request of film distributors, who want critics to delay writing long-form reviews until the films

${ }^{40}$ Jonathan Rosenbaum, "Film Writing on the Web: Some Personal Reflections," Film Quarterly 60, no. 3 (Spring 2007): 77.

${ }^{41}$ See work on the Moving Image Source website (http://www.movingimagesource.us) or the Vimeo group Audiovisualcy (http://vimeo.com/groups/audiovisualcy/). 
are officially released, in an effort to keep as much of the main theatrical-run audience as possible. Of course, if there is no official distribution in place, this threatens to marginalize lesshyped films into the group - a strange and unfortunate parallel to the critical mass mentioned above. Moreover, for media outlets, round-ups are a way for film critics to cover more films in a shorter amount of time in addition to giving them less strenuous individual assignments during the typically busy festival season, where a schedule three or four screenings per day — and sometimes more - is not unusual.

As I hope to show in the next section of this thesis, the shift to Internet-based criticism surrounding film festivals has in part homogenized reviews into a series of talking points that a critic must touch on to contextualize the film in question - these points often fall into the category of Czach's “critical capital” discussed earlier, which includes festival screenings and awards. As I will show in the case of two films - Uncle Boonmee Who Can Recall His Past Lives (2010) and The Turin Horse (2011) — these criteria play a major role in critical reception of films at three North American festivals, which have historically not hosted world premieres of international works and thus, as a result, the film in question already has a narrative arc in place over its festival life. However, also available to critics online is increased space when possible and the freedom that comes without a clearly defined readership (at least in relation to traditional print media), both of which potentially allow the critic to define and/or continue a larger discourse around a film. First, however, I must give a brief history of the three festivals in question in order to situate them within the larger festival world. 


\section{Three Paradigmatic North American Film Festivals}

Within that festival world, European events clearly dominate the calendar — in particular at Rotterdam and Berlin in January/February, Cannes in May, and Venice in September. ${ }^{42}$ The vast majority of North American festivals come late in the yearly cycle, with the exception of Sundance in January and South by Southwest in March (neither of these, notably, are known for their international focus, as they tend more toward programming new, independent American cinema). In fact, the yearly slate of international film festivals in North America predominantly occurs in either the clusters of March-April-May (including San Francisco, Seattle, Tribeca, Minneapolis/St. Paul, and Miami) or September-October-November (including Chicago, Denver, the Festival Nouveau Cinema in Montreal, Telluride, and Vancouver). Since distribution of films can sometimes be a slow process, the temporal spacing of festivals affects which films play at which festivals each year. For the first cluster, films from that year's Rotterdam and Berlin festivals may have a chance to make it into the lineup, but those from Cannes and Venice must wait until the next year. The second cluster is more open, as Rotterdam and Berlin films can easily make the lineup, Cannes films will have a chance, and Venice films will have to wait. It is precisely in this way that films are forgotten in the festival circuit, as the yearly onslaught never ceases; this is also why some North American festivals have particular programming biases, e.g. Cannes or Berlin heavy lineups.

The Toronto International Film Festival (TIFF), founded in 1976 as the "Festival of Festivals" but renamed in 1995, has become one of the biggest annual events on the festival calendar, regardless of location. The festival is traditionally held between the second and third

${ }^{42}$ Other premiere-heavy festivals, as mentioned in the introduction include Moscow in June, Karlovy Vary in July, Locarno in August, San Sebastián in September, BFI London and the Viennale in October, and Thessaloniki in November. 
weeks of September; TIFF has some overlap with Venice and comes approximately eight months after Sundance, seven months after Berlin and Rotterdam, four months after Cannes, and three months after Karlovy Vary — all major premiere festivals whose yearly crop often make the trek to Toronto. Originally designed to bring the best in world cinema to Toronto each year, which it still does, the festival has also morphed over time into an unofficial film market, where distribution deals are often made for North American theatrical and home video releasing. Reinforcing their status in the industry, TIFF is one of only five non-competitive festivals that the FIAPF (International Federation of Film Producers Associations) has accredited as of the 2012 cycle. $^{43}$ TIFF thus fits more closely to the mold of what Mark Peranson has called "business festivals," 44 in that it is both an unofficial market where distribution deals are solidified and a centralized spot for North American programmers to pick films for their festivals. However, TIFF also it attracts massive audiences on a yearly basis - over 400,000 at the 2010 edition, which helps the festival straddle the line between business and entertainment.

The New York Film Festival, somewhat unlike TIFF, has kept its "festival of festivals" status throughout its history. ${ }^{45}$ First formed in 1963 under the direction of Amos Vogel and Richard Roud - who, respectively, ran the independent/avant-garde cinema club Cinema 16, and was director of the London Film Festival — NYFF has been a mainstay of the New York film world ever since, bringing the latest in international cinema to the city (although much of their programming gets distribution shortly afterwards, so the festival can sometimes act as a

\footnotetext{
${ }^{43}$ See http://www.fiapf.org/intfilmfestivals_2011_sites03.asp for the official listing. The other four are the BFI London Film Festival, the Vienna Film Festival, the Kolkata (India) Film Festival, and the Norwegian International Film Festival Haugesund.

${ }^{44}$ Peranson, "First You Get the Money, Then You Get the Power," Dekalog 3: On Film Festivals.

${ }^{45}$ For a comprehensive study of the NYFF, see Rahul Hamid, "From Urban Bohemia to Urban Glamour: The Establishment and Early Years of the New York Film Festival," in Film Festival Yearbook 1, 67-81.
} 
preview event rather than a chance to see otherwise hard-to-find films). NYFF takes place around the transition from September to October (usually starting in the last week of September), roughly one-and-a-half weeks after TIFF ends. The festival is generally focused on the audience experience over market concerns, so there are a number of celebrities present during gala screenings and special events. The NYFF also brings many films' crews — usually directors, producers, and stars — to the festival for Q\&A sessions and the like.

The Portland International Film Festival, much like TIFF and the NYFF, is the most prominent organization bringing the latest in world cinema to its city, although as a smaller regional festival, PIFF does not have the clout of either in terms of bringing world or even U.S. premieres to its screens. Nor does PIFF feature the gala events of those two festivals, which are often full of celebrities, filmmakers, and other high-profile guests. What PIFF does, however, is offer its audiences a chance to see films that, by-and-large, have not secured distribution (with some that have), and thus will mostly never be seen theatrically in the city again. Founded in 1977, PIFF has seen a steady increase in attendance nearly every year; by 2012 , the festival had over 30,000 attendees. Contrast that to TIFF's 400,000 and NYFF's 75,000 and it is clear that PIFF does not have the sheer clout in world film culture, both economically and culturally, that TIFF and NYFF do. However, as Portland is much smaller than either Toronto or New York, PIFF inches closer in terms of local impact.

"Festival Films" and Online Press Coverage: Two Case Studies

\section{Apichatpong Weerasethakul's Uncle Boonmee Who Can Recall His Past Lives (2010)}

Thai filmmaker and visual artist Apichatpong Weerasethakul (b. 1970, Khon Kaen, Thailand) has, in the past several years, become something of a festival circuit darling for both programmers and critics with his enchanting, oblique works. His first feature film, Mysterious 
Object at Noon (Dokfa Nai Meuman, 2000), premiered at the International Film Festival Rotterdam where it had received funding through the festival's Hubert Bals Fund, and went on to festivals in Vancouver (where it won a special Dragons and Tigers Award), Jeonju, London, Singapore, and Hong Kong, among others. Apichatpong's second feature, Blissfully Yours (Sud Sanaeha, 2002), fared even better and built upon the modest success of Mysterious Object, winning the top prize in the Un Certain Regard sidebar at Cannes in 2002. In addition, the film subsequently played at festivals in Rotterdam (where it won the KNF award from Dutch critics), Locarno, Vancouver, Toronto, London, and BAFICI in Buenos Aires (garnering a director's award in addition to the FIPRESCI critics' prize). Tropical Malady (Sud Pralad, 2005), his third feature, made the main competition slate at Cannes that year, where it won a Jury Prize (considered the third most prestigious prize); further festival screenings included Toronto, New York, São Paolo, Vancouver, Rotterdam, Chicago, and London. Apichatpong's 2006 film Syndromes and a Century (Sang Sattawat), on the other hand, was met with mixed reactions from the festival juries; while it premiered at Venice and moved on to New York, Toronto, London, Vancouver, Tokyo's Filmex, Pusan, Rotterdam, and others, the film won no major, international-festival-specific awards.

From these various festival screenings and awards, we can clearly see the privileged position that Apichatpong's work holds in international film culture over the last decade. His films have screened at virtually all of the major European film festivals (Berlin is a notable exception) and have gone on to receive theatrical and home video distribution in Europe and North America. Theatrically, only Tropical Malady played beyond New York, with screenings in San Francisco, Seattle, Los Angeles, and Denver. Plexifilm released a DVD of Mysterious Object at Noon in 2003; Blissfully Yours, Tropical Malady, and Syndromes and Century have all 
been issued on DVD — in 2007, 2005, 2008, respectively — by Strand Releasing. ${ }^{46}$ Between festival screenings, accolades and general distribution patterns, Tropical Malady appears to be Apichatpong's most successful film, although that changed drastically with his most recent feature-length work, Uncle Boonmee Who Can Recall His Past Lives (Loong Boonmee Raleuk Chat, 2010), a co-production which secured funding from production companies based in Thailand, the U.K., France, Germany, Spain, and the Netherlands.

Uncle Boonmee, part of a wider multi-media project called Primitive (which features short films, installations, and texts ${ }^{47}$ ), tells the story of Boonmee, an elderly man on the brink of death due to impending kidney failure. He travels from a hospital to his family home deep in the farmland of Northern Thailand with a handful of distant relatives and an attendant, Tong, who is charged with making Boonmee's final days peaceful. As they settle in to their surroundings, one night the ghost of Boonmee's wife appears to take care of him, as does his long disappeared son (in red-eyed, ape-like form resulting from a mating experience with a "monkey ghost"). A trip into a cave where Boonmee was born in a past life, a short remembrance of his life as a catfish, and a documentation of the material and spiritual concerns following his surrender to kidney failure all follow in a loose narrative flow.

The $63^{\text {rd }}$ Cannes Film Festival competition lineup — likely the world's most prestigious competition, a berth in which is coveted by filmmakers worldwide - featured several very strong films, including Uncle Boonmee, Lee Chang-Dong's Poetry, Abbas Kiarostami's Certified Copy (starring French acting legend Juliette Binoche), Mike Leigh's Another Year,

\footnotetext{
${ }^{46}$ DVD release information attained via the DVD Aficionado website, http://www.dvdaf.com.

${ }^{47}$ For more information, see http://www.kickthemachine.com/works/Primitive\%20sub_website/ Primitive_Project/primitive_project.html, in addition to Apichatpong Weerasethakul, edited by James Quandt (Vienna: Austrian Film Museum, 2009) and Apichatpong Weerasethakul: Primitive, edited by Gary Carrion-Murayari and Massimiliano Gioni (New York: New Museum, 2011).
} 
Sergei Loznitsa's My Joy, and Xavier Beauvois's Of Gods and Men, among others. ${ }^{48}$ However, the competition jury — presided over by American filmmaker Tim Burton — awarded Apichatpong the Palme d'Or (Cannes' top prize and arguably the biggest festival award of the year) for Uncle Boonmee, a decision that, according to the New York Times' A.O. Scott, elicited “widespread surprise and a few eruptions of outrage.," ${ }^{, 49}$ Andrew O'Hehir of Salon notes: "this may be one of those rare occasions when the Palme d'Or actually has a commercial impact. Apichatpong's infinitesimal audience — limited so far to the most hardcore of art-film fans can only get bigger, and the global headlines resulting from this prize will certainly motivate some curious viewers. ${ }^{, 50}$ As is implied in O'Hehir's account, the Palme d'Or prize — or, for that matter, many other major Asian and European festival prizes — does not often translate into solid box office returns in North America (since 2000, only three Palme d'Or winners have come close to recouping production costs with U.S. box office receipts: Roman Polanski's The Pianist, Michael Moore's Fahrenheit 9/11, and Terence Malick's The Tree of Life).$^{51}$

Uncle Boonmee went into TIFF — where it was a North American premiere surrounded with a great deal of expectation and hype. The film was awarded a slot in the "Masters" section of the festival (which, according to TIFF, screens "films made by the most

\footnotetext{
${ }^{48}$ Neil Young, a critic based in the UK, gives his final odds for the 2010 festival's Palme d'Or competition at http://www.jigsawlounge.co.uk/film/reviews/cannes-2010-competition-odds/. Thirteen other films, not named above, competed for the Palme d'Or. A full list can be found at http://www.festival-cannes.fr/en/archives/2010/inCompetition.html.

${ }^{49}$ A.O. Scott, "A Farewell to This Life, and All Its Ghosts," New York Times, March 2, 2011, http://movies.nytimes.com/2011/03/02/movies/02uncle.html.

${ }^{50}$ Andrew O'Hehir, “Cannes Shocker: 'Uncle Boonmee' Wins,” Salon, May 23, 2010, http://www.salon.com/2010/05/23/palme_dor_cannes/.

${ }^{51}$ See http://www.boxofficemojo.com/genres/chart/?id=cannes.htm for a list of Palme d'Or winners and their attendant U.S. box office business for the years 1976 to 2010. Of note is Uncle Boonmee's spot at $29^{\text {th }}$ place out of 33 .
} 
influential directors living today, ${ }^{, 52}$ ), alongside new films from noteworthy, established filmmakers such as Jean-Luc Godard, Raul Ruiz, Manoel de Oliveira, and Ken Loach. Uncle Boonmee had already secured U.S. theatrical and home video distribution through Strand Releasing, ${ }^{53}$ although the general release was set to happen in Spring 2011, several months after the film's festival cycle. The distribution deal may have come about due to the prestige of the Palme d'Or in addition to Apichatpong's long relationship with Strand (who, as noted earlier, released three of his previous four features in the U.S.) - however, most curious is the nearly two-month delay between Uncle Boonmee's Cannes triumph and the solidification of the deal, since, more often than not, Cannes winners are picked up almost immediately.

In the lead-up to TIFF's 2010 edition (its $35^{\text {th }}$ ), the film industry news website Indiewire noted that Uncle Boonmee, as “winner of this year's Palme d'Or, Thai auteur Apichatpong Weerasethakul takes viewers on a subliminal journey through a cinematic border zone where magic, transmigration of souls and generations of memory cohabit in a highly original masterpiece. ${ }^{, 54}$ As Indiewire is one of the leading Internet-based sources of film news, their obligatory mention of the Palme d'Or sets a precedent for coverage to come; moreover, the language of "masterpiece" sets the film up as a hot commodity, but is not without a persuasive edge, especially in light of the "widespread surprise" Scott mentions in his New York Times review.

52 “TIFF Programmes,” Toronto International Film Festival, accessed April 30, 2012, http://tiff.net/thefestival/filmprogramming/programmes.

${ }^{53}$ Scott Roxborough, “Strand Picks Up 'Uncle Boonmee' for U.S.,” The Hollywood Reporter, July 6, 2010, http://www.hollywoodreporter.com/news/strand-picks-uncle-boonmee-us-25240.

${ }^{54}$ Peter Knegt, "TIFF List 2010: The Complete Toronto Film Festival Lineup," Indiewire, September 9, 2010, http://www.indiewire.com/article/tiff_list_2010_tracking_torontos_ announced_lineup/. 
TIFF round-ups tend to mention Uncle Boonmee as the Palme d'Or winner first and foremost, but also tend to use an incredulous tone when relating the film's story, as its strangeness for Western audiences seemingly must be considered. The National Post's Chris Knight notes the film's "sheer weirdness" as a factor while giving the film 2.5 stars out of $4,{ }^{55}$ whereas In Movies' David Humphreys says, when discussing Uncle Boonmee's plot divergences, that "[Boonmee's] son tells the story of how he became a ghost monkey, and the flashback that ensues is so deliriously strange that I began to suspect the kid at the concession stand of slipping something in my drink. ${ }^{56}$ However, previous exposure to Apichatpong's multifaceted and unusual work is key to understanding, so for $A . V$. Club critic Scott Tobias, the film is "probably his most accessible work to date, a moving and gently reassuring tale that softens the boundaries between man and nature, life and the afterlife," although he also notes its place in a long line of "beguiling (and occasionally baffling) experimental narratives." ${ }^{, 57}$ These roundups tie back to Scott's observation of shock at Cannes, which likely came from the experimental nature of Uncle Boonmee. Thus, reviews that focus on the film's Palme d'Or win in addition to its weirdness continue the dominant narrative that the film's Cannes success engendered.

Full-length TIFF reviews of Uncle Boonmee, on the other hand, offer a wider scope in their discussions while keeping the Palme d'Or central. In Exclaim, Robert Bell writes, "While indeed slow and willfully opaque, an almost eerie, lulling pace and the constant soundtrack of a living environment give us a sense of the otherworldly, exaggerating the possibilities of thematic

\footnotetext{
${ }^{55}$ Chris Knight, "TIFF Mini Reviews: Tender Son, Uncle Boonmee Who Can Recall His Past Lives," National Post, September 14, 2010, http://arts.nationalpost.com/2010/09/14/tiff-minireviews-tender-son-uncle-boonmee-who-can-recall-his-past-lives/.

${ }^{56}$ David Humphreys, “TIFF Day 6 and Day 7," In Movies, September 17, 2010, http://blog.inmovies.ca/2010/09/tiff-day-6-and-day-7-uncle-boonmee-trust-super-norwegianwood-tabloid.html.

${ }^{57}$ Noel Murray and Scott Tobias, "TIFF'10: Day 6," A.V. Club, September 15, 2010, http://www.avclub.com/articles/tiff-10-day-6,45189/.
} 
interpretation. Once again, Weerasethakul has delivered a uniquely compelling film to mull over and re-examine.. ${ }^{, 58}$ For Norm Wilner, "there's a generosity and warmth here that practically radiate off the screen; you can't help but be pulled along as Weerasethakul takes his odd, wonderful journey.. ${ }^{59}$ John Semley, writing for the Torontoist, sees Uncle Boonmee's crux as resting upon “[Boonmee's relatives'] arrival, reincarnated as ghosts and goofy-looking gorillas, [which] brings with it a shift in how Uncle Boonmee will live out his last days and how we must engage with Apichatpong Weerasethakul's truly masterful meditation on life, death, rebirth, and cinema itself. ${ }^{, 60}$ The aggregate of these reviews tells us that there is much more to Uncle Boonmee than just its "baffling" aspects (which, as an aside, are possibly only unusual to those without an understanding of the culture in which they are born — often a problem with 'festival films'). Only the critic who has the time and space to devote to the less esoteric aspects of the work is thus able to tell the potential audience more about the film on the whole, rather than paint it as a curiosity.

A spot in the "Masters" program at TIFF is certainly prestigious, but equally important is a berth in the New York Film Festival, which, contrary to TIFF's 300+ features, screened just thirty features in total at its 2010 edition ${ }^{61}$ However, rather than equal billing, films like The Social Network (David Fincher) and Hereafter (Clint Eastwood) took much of the spotlight with their opening and closing night slots, respectively. In a preview of the NYFF, Aaron Cutler of

\footnotetext{
${ }^{58}$ Robert Bell, "Uncle Boonmee Who Can Recall His Past Lives," Exclaim, accessed April 30, 2010, http://exclaim.ca/Reviews/TIFF/Uncle_Boonmee_Who_Can_Recall_His_Past_LivesDirected_by_Apichatpong_Weerasethakul.

${ }^{59}$ Norm Wilner, "Uncle Boonmee Who Can Recall His Past Lives," Now Toronto, accessed April 30, 2012, http://www.nowtoronto.com/guides/tiff/2010/listing.cfm?listingid=627. ${ }^{60}$ John Semley, "Uncle Boonmee Who Can Recall His Past Lives," Torontoist, September 8, 2010, http://torontoist.com/2010/09/uncle_boonmee_who_can_recall_his_past_lives/.

${ }^{61}$ The full lineup can be found at http://mubi.com/notebook/posts/new-york-film-festival-2010lineup.
} 
The House Next Door blog writes about these films' relation to the rest of the lineup: "to put this contrast in further perspective: Ruiz is the greatest Chilean filmmaker. De Oliveira is the best Portuguese. Apichatpong is the best Thai. Assayas comes second among current French filmmakers only to Claire Denis. Puiu is probably the best of the Romanian New Wave. Kiarostami is probably the single most important filmmaker of the past 20 years. Godard is probably the most important of the past 50. And chances are that, if you live outside of New York, you won't catch one of these movies in a theater." ${ }^{, 2}$ The dominance of the opening and closing films is confirmed in Indiewire's NYFF preview, where The Social Network and Hereafter are the first two films mentioned. ${ }^{63}$ If we recall Elsaesser's and Evans's arguments about the hegemony of Hollywood, the case of the NYFF is a clear example of the industry once again asserting its dominance within a film festival environment — this is also akin to Cannes' opening nights recently being populated with blockbuster American products, often screened out of competition so as to keep expectations high in the domestic market.

Some NYFF round-ups, much like those from TIFF, utilize the Palme d'Or as a key selling point for Uncle Boonmee. At Hammer to Nail, Nelson Kim notes, "once again, the arrogant elitists who pull the strings at the Cannes Film Festival have shown their contempt for ordinary moviegoers by awarding the Palme d'Or to this plotless, ponderous, and pretentious piece of... Just kidding. Apichatpong's latest is not only another triumphant addition to what's shaping up to be a legendary body of work; it's also probably his most accessible film yet, and thus nicely placed to benefit from the higher visibility and larger audiences the Palme is likely to

\footnotetext{
${ }^{62}$ Aaron Cutler, "New York Film Festival 2010: Preview," The House Next Door, September 16, 2010, http://www.slantmagazine.com/house/2010/09/new-york-film-festival-2010-preview/.

63 "New York Film Festival 2010: A Guide to All the Films," IndieWire, accessed April 30, 2010, http://www.indiewire.com/article/guide_new_york_film_festival.
} 
attract. ${ }^{, 64}$ For Kim, Uncle Boonmee seems to be a film that will sell itself largely off the strength of this one major award. However, at Movie Morlocks, R. Emmett Sweeney does not mention the Palme d'Or in his snippet review, instead opting to focus on the film's "endless strands to analyze and untangle, but...also the manifest pleasures of lolling in his gentle, comic rhythms and sparklingly beautiful compositions. ${ }^{365}$ From these two examples, the smaller profile and size of NYFF seems to make possible wildly differing analyses of films, as the festival caters to both those looking for the yearly "hits" (evidenced by NYFF's tiny lineup and relatively close proximity to many of its films' theatrical releases) and those looking for more underground and experimental fare, which often have more of an extended life thanks to those "endless strands" that Sweeney pinpoints.

Much like TIFF coverage, full reviews surrounding NYFF confirm the shift from Palmeheavy coverage to more thoroughgoing analysis of and engagement with at least certain elements of Uncle Boonmee as a text, rather than as a commodity. Michael Koresky of Reverse Shot begins his review by stating, "what should be mentioned first is the quiet. But when discussing Uncle Boonmee Who Can Recall His Past Lives many will undoubtedly initially gravitate towards the monkey ghosts, the talking catfish, the materializing spirits," going on to note that "Apichatpong has fashioned a film that is something like an endlessly regenerating tribute - to his father (who like Boonmee died of kidney failure), to cinema, to Thailand's Northern provinces, to the spirit world, to nature." ${ }^{66}$ Slant Magazine's Ed Gonzalez calls the film "coolly transfixed by the open-door relationship between the living and the dead," further

\footnotetext{
${ }^{64}$ Michael Tully, "Must-Sees at the New York Film Festival," Hammer to Nail, September 24, 2010, http://www.hammertonail.com/film-festivals/2010-new-york-film-festival-must-sees/.

${ }^{65}$ R. Emmett Sweeney, "The $48^{\text {th }}$ New York Film Festival, Part 2," Movie Morlocks, September 28, 2010, http://moviemorlocks.com/2010/09/28/the-48th-new-york-film-festival-part-2/.

${ }^{66}$ Michael Koresky, “Jungle Fever," Reverse Shot 28, accessed April 30, 2010, http://www.reverseshot.com/article/uncle_boonmee_who_can_recall_his_past_lives.
} 
noting that late in the film, Apichatpong "gets provocative, slyly addressing the oppressive forces that not only control the lives of his fellow Thai countrymen but also keep a close eye over his work." ${ }^{67}$ Finally, Cutler, in his review of Uncle Boonmee, notes that the film "startles you with effects that go back to cinema's origins, a technique that paradoxically feels more revolutionary than regressive," also positing that "it's rare for a movie to simultaneously evoke nostalgia and anticipation. The future that Uncle Boonmee suggests is bright." ${ }^{68}$

Cutler's simultaneously elegiac and optimistic take on the film and film culture as a whole, in the face of its much written-about demise, sets Uncle Boonmee apart from the award that fueled much of the critical accounts leading up to and happening during the NYFF in 2010. It seems that the miniscule lineup of NYFF, when compared to TIFF's 300+ feature films, can be adequately posited as the reason behind the relative lack of Palme d'Or mentions by critics. Where Uncle Boonmee needed all the help it could get to stand out from the TIFF crowd, at the NYFF this does not seem to be as large a problem — all films shown there stand out, especially in a city the size of New York. As NYFF is one of the foremost film events on New York's calendar, a spot in the festival is undoubtedly a sign of a film's success, in this most boutiquelike of festivals. From this, by the end of NYFF, it seems the film had found a life of its own on the festival circuit.

Uncle Boonmee, then, also had its reputation as at least a "minor" masterpiece essentially solidified by the time it was announced as part of the $34^{\text {th }}$ Portland International Film Festival in

${ }^{67}$ Ed Gonzalez, "Uncle Boonmee Who Can Recall His Past Lives," Slant Magazine, September 21, 2010, http://www.slantmagazine.com/film/review/uncle-boonmee-who-can-recall-his-pastlives/5031.

${ }^{68}$ Aaron Cutler, "New York Film Festival 2010: Uncle Boonmee Who Can Recall His Past Lives," The House Next Door, September 23, 2010, http://www.slantmagazine.com/house/2010/09/new-york-film-festival-2010-uncle-boonmeewho-can-recall-his-past-lives/\#more-17396. 
January 2011. In the lead up to the festival, however, the focus was once again on the Palme d'Or. Both the Oregonian and the Portland Mercury, two of the city's top news outlets, mention the award in their snippet reviews, which are each short on space (two and one paragraphs, respectively). ${ }^{69}$ Chris Stamm, writing for the Willamette Week, calls the film "Cannes-laureled," a descriptor halfway between acknowledgment and obscurity; this is preceded by the confession that Stamm fell "in love with the medium all over again" while watching Uncle Boonmee, which he urged viewers to see twice during the festival. ${ }^{70}$ Stamm's statement is in line with earlier pronouncements about the work's ties with film history (particularly Cutler's NYFF review), which furthers the shift from award-focused criticism to engagement with the film's place in cinema culture more broadly — something that only happens with time.

As we can clearly see from Uncle Boonmee, coverage at PIFF pales in both breadth and depth when compared to the critical apparatus surrounding TIFF and NYFF. There are fewer news outlets specifically dedicated to film in Portland, thus forcing its residents and viewers who seek a wider discourse surrounding a film to go elsewhere. As PIFF happens annually in February, this is relatively easy since the majority of other North American festivals, as noted earlier, happen in the March-April-May and September-October-November clusters. Thus, most PIFF films have already played at several festivals on the continent, and there is already a strong batch of views from critics nationwide.

Critical opinion, as we have seen, was very kind to Uncle Boonmee through its North American festival run, so it seems plausible to suggest that it did not have a negative impact on

\footnotetext{
${ }^{69}$ Shawn Levy, "PIFF34: Week One Reviews," Oregonian, February 10, 2011, http://blog.oregonlive.com/madaboutmovies/2011/02/piff34_week_one_reviews.html, and Jamie S. Rich, "Film Shorts," Portland Mercury, February 10, 2011, http://www.portlandmercury.com/ portland/film-shorts/Content?oid=3350737.

${ }^{70}$ Chris Stamm, "PIFF Rolls East," Willamette Week, February 16, 2011, http://wweek.com/portland/article-16970-piff_rolls_east.html.
} 
theatrical distribution. However, as mentioned earlier, Uncle Boonmee fared relatively poorly at the U.S. box office - especially when compared to other Palme d'Or winners - where to date it has made only $\$ 184,000$ in gross sales, showing at just six screens simultaneously and opening on just three screens in its first week. ${ }^{71}$ Film Comment, in their annual "Grosses Gloss" piece, which runs down all theatrically released films for the previous year, places Uncle Boonmee box office figure in the "solid" category (which also includes such critical hits from 2011 as Meek's Cutoff, Melancholia, Poetry, Le Havre, The Interrupters, and others). ${ }^{72}$ In extreme contrast, Sherlock Holmes: A Game of Shadows (2011), also in Film Comment's "solid" category, earned \$504.7 million - of course, that film was produced and distributed by Warner Brothers, one of the biggest studios in Hollywood, so the relationship between money spent, money made, and overall expectation is quite different. But the comparison brings up the issue of the American film industry's unofficial distribution channels, where certain types of films — foreign, documentary, independent — are forced to eke out a meager existence on the nationwide circuit of independent theaters, predicated on the film securing distribution at all, while Hollywood blockbusters routinely open on 3,000 or more screens.

\section{Béla Tarr's The Turin Horse (2011)}

Much like Apichatpong, Béla Tarr (b. 1955, Pécs, Hungary) has essentially made his filmmaking career at festivals, although his work has become increasingly spaced wider apart over time. Known for his slow, repetitive narratives, Tarr has become something of a cult hero in the festival world for his continued embrace of shooting on celluloid. His films have all been

\footnotetext{
${ }^{71}$ Sales figures come courtesy of the Internet Movie Database (http://www.imdb.com). According to the National Association of Theatre Owners, as of 2009 there were 39,233 screens in the U.S., of which six is roughly $.0001 \%$. See http://www.natoonline.org/ statisticsscreens.htm for a screen tally by year.

72 “"The $37^{\text {th }}$ Annual Grosses Gloss," Film Comment 48, no. 2 (March-April 2012): 54-59.
} 
shot on film, and all with the exception of The Outsider and Almanac of Fall are in black-andwhite. In addition, the aspect ratio of his work through Almanac of Fall is 1.37:1, with everything after being 1.66:1 — the former being a holdover from the classical Hollywood and early television days, the latter being a ratio inaugurated in late in the studio system (the early-tomid 1950s) and subsequently a stalwart of the post-war European art cinema boom. ${ }^{73}$

Tarr's first feature film, Family Nest (Családi Tüzfészek, 1979), premiered in his native Hungary but failed to hit the festival circuit until 2002, when the film screened at the Thessaloniki International Film Festival during a retrospective of Tarr's work (the film also screened during a retrospective at the Moscow Film Festival in 2011). Tarr's 1981 film The Outsider (Szabadgyalog) did not receive domestic distribution in Hungary, and was only screened theatrically at the Thessaloniki and Moscow retrospectives. His next film, Prefab People (Panelkapcsolat, 1982), also part of those festival retrospectives, was only released in Hungary — and, like the previous two works, failed to garner international attention. With 1984's Almanac of Fall (Öszi Alamanch), Tarr finally entered international consciousness as the film premiered at the Locarno Film Festival in Switzerland where it won the short-lived Ernest Artaria Award (1977-1989), and the film was released in Hungary in early 1985. Damnation (Kárhozat, 1988) built on the relative success of Almanac of Fall — the film premiered at the Berlinale in early 1988 and went on to TIFF, but still only received theatrical release in Hungary and the Netherlands. The seven-hour Sátántangó (1994), arguably Tarr's most revered work, was an unprecedented hit relative to his earlier works. The film premiered at the Hungarian Film Festival in February 1994, played Berlin in the Forum sidebar soon thereafter, and went on to the

\footnotetext{
${ }^{73}$ Notable films shot in 1.66 include Andrei Tarkovsky's last two films, Nostalghia (1983) and The Sacrifice (1986), Robert Bresson's L'Argent (1983), Stanley Kubrick's A Clockwork Orange (1971) and Barry Lyndon (1975), and Alfred Hitchcock's North by Northwest (1959), among others.
} 
NYFF that fall and TIFF in 1995. At Berlin, the film won the Caligari Film Award, which awards one film from the Forum (young filmmakers) section for stylistic innovation. After a sixyear wait, Tarr and his collaborators made Werckmeister Harmonies (Werckmeister Harmóniák, 2000), which premiered at Cinedecouvertes in Brussels and played TIFF (in the "Masters" section), Berlin, Cannes, Ediburgh, Rotterdam, Warsaw and Chicago. The film won several awards in Hungary, including prestigious film critics' awards, in addition to a special award of the reader jury at Berlin. Additionally, Werckmeister Harmonies was the first Tarr film to receive a U.S. theatrical run (albeit solely in New York City). In 2007, Tarr produced The Man from London (A Londoni Férfi), a thriller based on French novelist Georges Simenon's work of the same name. The film premiered in competition at Cannes and played Karlovy Vary, TIFF, the NYFF, Chicago, and São Paolo but failed to receive awards at any festival, and was generally a critical disappointment.

The career of Béla Tarr is also noteworthy for his engagement in three very lengthy collaborations: with his longtime partner and wife of 27 years, Ágnes Hranitzky, who has worked variously as production designer, editor, and co-director in each of Tarr's films since The Outsider; with the novelist László Krasznahorkai, who has written source novels and screenplays for each of Tarr's post-Almanac of Fall films; and with composer Mihály Vig, who has scored all of Tarr's films since Almanac of Fall. To call Tarr an auteur in the strict sense (as Andrew Sarris might have during the auteurist heyday of the 1960s) severely understates the value of these collaborations, but for the sake of simplicity I refer to the films as his throughout this analysis.

As noted above, distribution of Tarr's films in the U.S. has been scant, with only one film — Werckmeister Harmonies — playing outside of a festival in this country. Home video has 
been almost equally unkind, although recent years have seen a renaissance of Tarr works available on DVD. In 2005, Chicago-based distributor Facets Multimedia released a three-disc boxed set containing Family Nest, Prefab People, and The Outsider, and has subsequently released stand-alone editions of Almanac of Fall, Damnation, and Werckmeister Harmonies in 2006 and a three-disc set of Sátántangó in 2008. The order of these releases — while following chronology — is curious, as Tarr's later, mature works were on the whole more critically acclaimed; in addition, as the films' festival lives as detailed above show, these later films had more exposure and traction with general audiences. Again, this contrasts with Apichatpong's works distributed by Strand, which began with the most popular work (Tropical Malady) and continued chronologically from there. The kind of release schedule Facets gave Tarr's works risked alienating first-time viewers by offering "lesser" — i.e. earlier, more obscure — films before those that had some success on the international festival circuit. The Man from London, a work from 2007, received a heavily delayed DVD release in early 2012 by Zeitgeist Films, again signaling the assumedly tiny audience his films have stateside.

After his relatively turbulent festival career (especially when contrasted with Apichatpong's meteoric rise), Tarr's most recent film, 2011's The Turin Horse (A Torinói Ló), received a great deal of international attention — possibly due to the strength of the film, but also possibly due to the fact that Tarr has repeatedly stated that the film will be his last. ${ }^{74}$ This decision, Tarr tells the Huffington Post, came about "because during 34 years I have done

\footnotetext{
${ }^{74}$ See, among many others, Nicolas Rapold, "In Auteur's Swan Song, an Ode to Survival," The New York Times, February 3, 2012, http://www.nytimes.com/2012/02/05/movies/bela-tarr-saysthe-turin-horse-is-his-last-movie.html.
} 
everything I want, what I want to show you, it's done."75 The Turin Horse begins with a cryptic voiceover:
"In Turin, on the third of January in 1889, Friedrich Nietzsche steps out of the door of Number Six Via Carlo Alberto - perhaps to take a stroll, perhaps to go by the post office to collect his mail. Not far from him, or indeed very removed from him, a cabman is having trouble with his stubborn horse. Despite all his urging, the horse refuses to move, whereupon the cabman - Giuseppe? Carlo? Ettore? - loses his patience and takes his whip to it. Nietzsche comes up to the throng and puts and end to the brutal scene of the cabman, who by then is foaming with rage. The solidly built and full-moustached Nietzsche suddenly jumps up to the cab and throws his arms around the horse's neck, sobbing. His neighbor takes him home, where he lies still and silent for two days on a divan until he mutters the obligatory last words: "Mutter, ich bin dumm" and lives for another ten years, gentle and demented, in the care of his mother and sisters. Of the horse, we know nothing." 76

From there, the film shows us Tarr's vision of what happened to the horse; Nietzsche never appears in the film as such, although his presence looms large. The film concerns the cabman and his daughter, who eke out meager lives on a windswept plain just outside of town, relying on the horse for their livelihood. When the animal refuses to move the day following Nietzsche's breakdown, both father and daughter are forced to confront their mortality; daily routine becomes haunting, and the bleak and oppressive nature of this particular northern Italian landscape become overwhelming.

The Turin Horse received its world premiere in February 2011 at the $61^{\text {st }}$ Berlinale where "among cinephiles the most anticipated competition entry by far was The Turin Horse, the latest — or, as he has claimed, the last — movie by the Hungarian master of miserablism Béla Tarr," writes Dennis Lim in a Berlinale recap. ${ }^{77}$ At the end of the festival, the film was awarded both the FIPRESCI film critics’ prize and the Silver Bear for Jury Grand Prix — considered the festival's second-most prestigious prize — by an international jury headed by Italian actress

\footnotetext{
75 Amy Lee, "Béla Tarr on 'The Turin Horse': The Hungarian Director Discusses His Last Film," The Huffington Post, February 10, 2012, http://www.huffingtonpost.com/2012/02/10/bela-tarrthe-turin-horse n_1266397.html.

${ }^{76}$ Béla Tarr, The Turin Horse (New York: Cinema Guild, 2011), film.

${ }^{77}$ Dennis Lim, "Somber Themes Dominate Berlinale," The New York Times, February 16, 2011, http://www.nytimes.com/2011/02/17/arts/17iht-berfest17.html?_r=1.
} 
Isabella Rossellini. Following its Berlinale success, throughout 2011 the film played several major festivals including CPH:PIX in Copenhagen, BAFICI, Edinburgh, Melbourne, Karlovy Vary, and Telluride before making its way to TIFF. Like Uncle Boonmee the previous year, The Turin Horse was awarded a slot in TIFF's “Masters" section (as had Werckmeister Harmonies), a berth compounded by the "final" status of the work — if Tarr is indeed a master of world cinema (an argument with little to no opposition), it stands to reason that his final film would be a major event, as it was in each festival to which it traveled through the year. Its TIFF engagement was no different.

However, the Berlin awards won by The Turin Horse are nowhere to be found in the vast majority of TIFF reviews, both round-up and full-length. This can be explained in a number of ways: neither award was the 'top' prize at the festival, Berlin is three months earlier in the year than Cannes and so the awards were less fresh in critics' minds, or Berlin does not have the same level of respect and authority in world film culture as do other festivals, most particularly Cannes. This last reason seems most likely, as Cannes has long dominated the European film festival scene.

At the Torontoist, John Semley says of the film: "essentially a long, bleak, 'what if'...Tarr's mannered camera movements may have you pining for the more rhapsodic bob and weaves of his masterpiece, 2000's Werckmeister Harmonies. Still if it is indeed Tarr's final film (as he claims), The Turin Horse's crawling, ponderous descent into apocalyptic blackness seems fittingly, despairingly, apropos. ${ }^{.78} \mathrm{He}$ also notes, in a subtitle, that The Turin Horse is Tarr's "(alleged) final film." At Twitch Film, Michael Guillen mentions the film's Berlin win in passing (calling it a "Berlinale winner") before moving into his analysis of the film, which he calls

\footnotetext{
78 John Semley, "The Turin Horse," Torontoist, September 8, 2011, http://torontoist.com/2011/ 09/the-turin-horse/.
} 
"exacting but exquisite" while "the look of the film remains unquestionably beautiful, if daunting. Tarr's pacing, of course, is an acquired taste, if not an exercise in patience. His is the proverbial 'difficult' film." ${ }^{, 79}$ During this review, Guillen also uses the "(alleged)" label when referring to the film's "final" status, in an echo of Semley's review only five days earlier. Ben Kenigsberg, writing for Time Out Chicago, the "studied bleakness" at work in the film "can be intellectually defensible...but to my mind, the structure in The Turin Horse isn't actually particularly innovative, and the humorlessness makes the film punishing to watch," mentioning neither the Berlin awards nor The Turin Horse's "last film" potential, ${ }^{80}$ both of which seem only applicable, and appropriate, when the critic in question reviews the film positively. Finally, in a round-up on the last day of TIFF, Kiva Reardon writes that The Turin Horse is "long, beautiful and ultimately about the descent into nothingness...seems like a symbolic good fit as with the end of the festival" ${ }^{\prime 1}$ - at this point, the film had already screened twice, ${ }^{82}$ so mentions of anything contextual by then seem unimportant, as those who hotly anticipated the film would have likely already seen it.

From these reviews, it is apparent that The Turin Horse's reception, in terms of immediately graspable themes and elements, has been far more slippery and evasive than the majority of films released in a given year. Coverage of the film by online critics, when compared to that of the previous year's Uncle Boonmee, was down in both overall number and average

\footnotetext{
${ }^{79}$ Michael Guillen, “TIFF 2011: The Turin Horse," Twitch Film, September 13, 2011, http://twitchfilm.com/reviews/2011/09/tiff-2011-the-turin-horse.php.

${ }^{80}$ Ben Kenigsberg, "Toronto International Film Festival 2011: Anonymous, The Turin Horse, The Deep Blue Sea," Time Out Chicago, September 16, 2011, http://timeoutchicago.com/artsculture/film/14947303/toronto-international-film-festival-2011-anonymous-the-turin-horse-thede.

${ }^{81}$ Kiva Reardon, “TIFF Review Roundup: September 18,” Torontoist, September 18, 2011, http://torontoist.com/2011/09/tiff-review-roundup-september-18/.

${ }^{82}$ See http://tiff.net/filmsandschedules/tiff/2011/turinhorse for specifics.
} 
length. This can possibly be attributed to the more challenging films of Tarr, who has a very cultlike following among hardcore cinephiles, but can also be a case of diminished "critical capital $^{\prime 83}$ - Berlin has a lower international profile than Cannes and The Turin Horse's Grand Prix is less prestigious than the Palme d'Or. These factors weigh heavily into who covers the film, which is borne out at TIFF, as major news outlets failed to publish pieces about the film, leaving it almost exclusively to bloggers. In addition, since Berlin occurs much earlier in the calendar than Cannes, its awards may well be forgotten by the time the fall festival season rolls around, thus another possible source for critics' lack of attendant coverage to The Turin Horse's award.

Naturally, none of this was the case at 2011's NYFF, where the film was highly anticipated by critics and audiences alike. In online festival previews, both The New York Times and The L Magazine put stills from The Turin Horse front-and-center in their coverage, prioritizing the film above other prominent NYFF selections,${ }^{84}$ which included Asghar Farhadi's Nader and Simin, A Separation (which won Oscar for Best Foreign Film), the Dardenne Brothers' The Kid with a Bike, Wim Wenders's Pina, and Lars Von Trier's Melancholia. In addition, the opening and closing night films, Roman Polanski's Carnage and Alexander Payne's The Descendants are not placed in primary positions for either piece. From these two previews, we can see that The Turin Horse would be a hot ticket at the NYFF — a proposition that the reviews confirmed.

\footnotetext{
${ }^{83}$ Czach, "Film Festivals," 82.

${ }^{84}$ Manohla Dargis, "Cult Hits, Carnage, and Even Chaplin," The New York Times, September 29, 2011, http://www.nytimes.com/2011/09/30/movies/new-york-film-festival-now-biggerbeckons.html and Mark Asch, "New York Film Festival Lineup Announced," The L Magazine, August 17, 2011, http://www.thelmagazine.com/TheMeasure/archives/2011/08/17/new-yorkfilm-festival-lineup-announced.
} 
In a pre-festival review for The House Next Door, Andrew Schenker writes: "Béla Tarr is the cinema's greatest crafter of total environments and in The Turin Horse, working in his most restricted physical setting since 1984's Almanac of Fall, he (along with co-director Ágnes Hranitzky) dials up one of his most vividly immersive milieus," going on to state that "if ever a film had a claim to being profound in its banality, The Turin Horse is it." ${ }^{85}$ Nowhere in his piece does Schenker mention the previous successes of the film nor does he allude to Tarr's 'retirement,' instead opting to fully engage with the film as a text. Continuing this line is Tom Hall at Indiewire, who calls the film Tarr's "latest masterpiece," further noting that "as always, Tarr's stunningly photographed long takes will test some viewers' ability to pay continuous attention, but they are, for those who care to look, absolutely audacious and thrilling." Hall concludes that "those who give themselves over to Tarr's vision will be rewarded with a rich, deeply moving story, a movie of incredibly mastery and power that ranks among the director's finest works. ${ }^{" 86}$ Hall's engagement with Tarr's entire career (which is alluded to at several points) points to both the anticipation among fans of the director's work and also to the importance of contextualizing "festival films," which are quite often very far removed from the culture in which they are screening.

Furthering the narrative of a continuum, Christopher Bell, writing for The Playlist, eulogizes Tarr's career beyond the perfunctory retirement mention, calling it "such a loss. We're not only losing a fantastic artist; we're losing the one person that continued an undiluted method

\footnotetext{
${ }^{85}$ Andrew Schenker, “The Turin Horse," The House Next Door, September 27, 2011, http://www.slantmagazine.com/film/review/the-turin-horse/5789.

${ }^{86}$ Tom Hall, "Beasts of Burden: Béla Tarr's The Turin Horse," Indiewire, October 5, 2011, http://blogs.indiewire.com/twhalliii/the_2011_new_york_film_festival_beasts_of_burden_the_ turin_horse.
} 
of a generation long gone. ${ }^{" 87} \mathrm{He}$ also gets at the film's polarizing nature: "Quite unforgettable, whether you fancy it or not," a notion that several critics use in relation to almost all of Tarr's films, which makes them paradigmatic of the "festival style" of film — slow, bleak, and lacking dialogue, but very beautiful. In fact, most critics also note the extreme length of shots in the The Turin Horse - "Long long long long shots (no surprises here)," notes The L's Sarah Lerner ${ }^{88}$; Bell thinks that "no shot is too long for this filmmaker, and he does as much as he can in an uninterrupted take, making every minute spent with this unfortunate family feel even heavier." ${ }^{\prime 89}$ These long takes, a mere seven months after the film's premiere at Berlin, include the "nowfamous tracking shot"90 of the titular horse struggling through the wind after its encounter with Nietzsche. ${ }^{91}$ Tarr's career has been in part made by a staunch opposition to mainstream filmmaking methods, although the long-take aesthetic has become something of a standard on the festival circuit. Thus, those critics like Schenker, Bell, and Hall who devote space to mentioning Tarr's full body of work implicitly place him as a key figure (alongside filmmakers like Andrei Tarkovsky) in a long-gestating stylistic tendency.

Screenings of The Turin Horse were so successful that upon the film's regular New York theatrical release in January 2012, the Film Society of Lincoln Center - the parent company of the NYFF — hosted a full retrospective of Tarr's works. The audience for these films is certainly there in New York, as evidenced by the quick, three-month turnaround from festival to

${ }^{87}$ Christopher Bell, "NYFF '11 Review: Béla Tarr's Swansong 'The Turin Horse' is Despairing But Unforgettable," The Playlist, October 9, 2011, http://blogs.indiewire.com/theplaylist/nyff_ review_bela_tarrs_swan_song_the_turin_horse_is_despairing_but_unforget.

${ }^{88}$ Sarah Lerner, "NYFF 2011: The Turin Horse," The L Magazine, October 12, 2011, http://www.thelmagazine.com/TheMeasure/archives/2011/10/12/nyff-2011-the-turin-horse.

${ }^{89}$ Bell, op. cit.

${ }^{90}$ Phil Coldiron, "NYFF '11 Review: Tarr's Final Testament," Fandor Keyframe, October 11, 2011, http://www.fandor.com/blog/nyff-11-review-fade-to-black-the-turin-horse/.

${ }^{91}$ This scene, which includes the prologue to the film, can be viewed at http://www.youtube.com/watch?v=v32n4lCG0OA. 
retrospective. In November 2006, Portland's Northwest Film Center - the parent organization of PIFF — produced a partial retrospective of Tarr's work, which included Damnation, Sátántangó, and Werckmeister Harmonies. However, Tarr's later The Man from London (distributed by IFC Films, arguably the most prominent independent distributor in the U.S. market) in addition to any of his pre-Damnation works have never screened in the city as of 2012. Thus, audiences in the city would have been at least somewhat familiar with Tarr's most popular works going in to the 2012 edition of PIFF, where The Turin Horse was scheduled to screen twice, both in the festival's second week.

As such, The Turin Horse was not a highly anticipated film among Portland critics. In PIFF previews, The Turin Horse went unmentioned, and only three brief reviews appeared online - all of which were from primarily print outlets. In The Willamette Week, Aaron Mesh notes that this is the film with which "Béla Tarr concludes his notoriously snail-like career,",92 alluding to both Tarr's relatively small output (nine films over 33 years) and the pacing of his films - two key considerations to placing Tarr's work within the larger history of art cinema. But Mesh does little more with the space allotted to the film, only noting its emptiness and lack of propulsive narrative. The Portland Mercury, one of Portland's leading weekly newspapers, neglected to cover the film at all, only offering the distributor's synopsis on their website in place of a review.

In a blog post for The Oregonian, Shawn Levy begins with a meta-narrative: he "was given a DVD screener of Hungarian director Béla Tarr's latest film only to discover upon watching it that it wasn't subtitled. But, knowing that Tarr often works in long takes with little or no dialogue, I decided to stick with it anyhow, if only to get a sense of things. As it happened,

92 Aaron Mesh, "Licking PIFF," The Willamette Week, February 15, 2012, http://wweek.com/ Portland/article-18818-licking_piff.html. 
I watched it all, and while I surely missed a great deal, I came away with some very strong and favorable impressions. ${ }^{, 93}$ All of the information about Nietzsche and all of the dialogue are rendered unintelligible — in Levy's view, what shines through is the film's cinematography, "shot in black-and-white with exceedingly lengthy and intricately choreographed takes" and its music, which for Levy conveys "architectural profundity." " His review is refreshingly honest, as not only does it take the film at face value, without contextual clues, but it also places the film on a plane of purely visual and non-dialogic sound, two facets of festival films that are often only analyzed in relation to narrative.

Unlike Uncle Boonmee, which by all accounts was a resounding critical success, The Turin Horse was met with somewhat disparate views about its place in the yearly crop of festival films. On one hand, Tarr's film was anticipated and subsequently well-reviewed by cinephile critics familiar with the director's previous works; on the other hand, many critics lamented the bleakness and despair present in the film, and it was lost in the festival shuffle for them, just another film in an endless string of films. Whatever the view, as we have seen almost all critics neglected to forefront the film's success at Berlin or other festivals.

At the time of this writing, The Turin Horse was still in its initial theatrical run handled by New York-based distributor Cinema Guild. After its festival life, the film has been released in just fewer than 30 theaters nationwide and has grossed just over $\$ 44,000 .^{95}$ The film appears to be on a financial trajectory similar to that of Uncle Boonmee; it will surely break the $\$ 100,000$

\footnotetext{
93 Shawn Levy, "Portland International Film Festival Reviews," The Oregonian, February 16, 2012, http://blog.oregonlive.com/madaboutmovies/2012/02/portland_international_film_fe_ 3.html.

94 Ibid.

${ }^{95}$ Figures courtesy Cinema Guild's website, http://www.cinemaguild.com and Box Office Mojo, accessed May 16, 2012, http://boxofficemojo.com/movies/?id=turinhorse.htm.
} 
mark, but anything more is relatively unrealistic when faced with the distribution channels and hierarchies present within American film culture — especially for slow foreign films.

\section{Conclusions}

As I have shown above, both Uncle Boonmee and The Turin Horse were well received on the North American festival circuit, albeit to differing degrees. Where Uncle Boonmee's Palme d'Or was a key consideration for most critics, The Turin Horse's Berlin win was less of a selling point in reviews of that film. But neither of these awards, in the grand scheme, will mean much to either film.

Despite critical reception, however, the films, in my view, received lackluster distribution and exhibition opportunities, which on the whole limited their chances to be seen by wider audiences (although in relation to the vast majority of festival films, they are juggernauts). However, this does not preclude the films from being discussed, analyzed, dissected by critics and scholars in the future, since each did secure home video distribution (Uncle Boonmee has been released on DVD and Blu-Ray by Strand, and The Turin Horse's release on those formats is scheduled for July 2012).

According to Janet Staiger, in her landmark article on film canons, "in film criticism, whether popular or academic, some films will be chosen for extensive discussion and analysis; others will be ignored." 96 She differentiates between two groups of critics with competing value systems: "auteur critics" and "ideological critics," who look for different types of representation, stylistic tendency, narrative focus, and other filmic elements in order to judge particular works. ${ }^{97}$ In the case of both Uncle Boonmee and The Turin Horse, judgment by online critics came almost exclusively in the form of auteurist critique. However, within their respective home cultures,

\footnotetext{
96 Janet Staiger, “The Politics of Film Canons," Cinema Journal 24, no. 3 (Spring 1985), 4. 97 Ibid., 11.
} 
both films can be viewed as highly political. In the former case, Boonmee talks about how he killed too many Communists and bugs, in addition to making several denigrating comments about Laotians who have immigrated to Thailand. Furthermore, Apichatpong's prior works are heavily engaged with the political and social history of Thailand, and although scholarly studies of his work have been extremely spare to this point, this through-line within his work is ripe for future analysis. Staiger posits that “employing a 'masterpiece-only' approach can suppress a number of interesting questions about styles, genres, national movements, and the relation between signifying practices and groups of people (as work on cultural studies and ideology has shown." 98 If Uncle Boonmee is a masterpiece now (as many have posited), its standing will surely shift over time, as Apichatpong has only just entered his 40s, and will undoubtedly make many more films — the succession of which will place each preceding film within an everwidening body of work. In addition, as he is one of the first Thai filmmakers to have international success (especially at such a high level), his style will possibly influence others to the point of the creation of a new national movement — which will have its own attendant issues to be analyzed.

In the case of The Turin Horse, Tarr has repeatedly stated that it is his last film - he has already said everything he needs to. His dissatisfaction with the official Hungarian film apparatus has been widely noted, and can be plausibly asserted to be part of his decision to retire from filmmaking. ${ }^{99}$ It is this political engagement and explicit refusal to work within that system that should make possible several angles of ideological critique in relation to Tarr's work. Furthermore, his previous films, much like Apichatpong's, deal with political and social issues

\footnotetext{
${ }^{98}$ Ibid.

${ }^{99}$ Geoffrey Macnab, “Béla Tarr Flies Hungarian Flag,” Screen Daily, February 10, 2012, http://www.screendaily.com/news/europe/bela-tarr-flies-hungarian-flag/5037722.article\#.
} 
vital to Hungarian culture, albeit usually in a highly allegorical manner. Again, in a mirror of Apichatpong's work, scholars have done little work with this area of Tarr's films; the usual critiques are his films' slowness, bleakness, and despair, but these qualities are rarely discussed in service of big-picture ideas as they are more tied to stylistic tendencies that have become dominant within the film festival world over the past 30 years.

Peter Wollen, another theorist of the canon, says:

"There are too many reasons why we have a canon. Basically, because priorities are set within practical limits of money, time, and enthusiasm in every area from archives through universities to publishers and, in a community where there is some amount of intersubjective communication, these will tend to reinforce each other. It is for this reason that I think it is important to look carefully at how canons are constructed and what they indicate. Finally, I think aesthetics is central to film study and that since aesthetic inquiry necessarily involves judgments of quality, this must lead to debates over value and taste which will in turn lead to reassessments of the existing canon." 100

It remains to be seen if either of these films will enter the canon proper, or what that canon will consist of in the future and how it will be decided upon. When judged on aesthetic quality alone, both films would seem to be primary candidates for future study. However, following Staiger, it remains to be seen if these works will be looked at for their trenchant social and political critiques.

As we have seen with online film criticism (at least surrounding these two instances of award-winning films playing at North American festivals), the discourse mostly resembles traditional print media in both topic and scope. However, the sheer number of critical outlets — both formally, e.g. aggregators, and organizationally, e.g. online film magazines — present on the Internet when compared to the print media allow it an increasingly prominent voice in the debates that Wollen calls for. As I have showed in my analysis of the critical discourse surrounding Uncle Boonmee and The Turin Horse, ${ }^{100}$ Peter Wollen, "The Canon," Chap. 15 in Paris Hollywood: Writings on Film (London: Verso,
2002), 232. 
the conversation shifts from the films' surface to greater depth as they travel through the festival circuit and into theatrical and home video distribution. Hopefully, the scholarly discourse around the films themselves and their engagement with real social and political ideologies also continues to widen with time - either that, or the films will be nothing more than a lost memory, invisible precursors to following generations of filmmakers who will engage with their own set of social and political — not to mention aesthetic issues. 


\section{Bibliography}

“The $37^{\text {th }}$ Annual Grosses Gloss," Film Comment 48, no. 2 (March-April 2012): 54-59. Allen, Richard. Projecting Illusion: Film Spectatorship and the Impression of Reality. Cambridge and New York: Cambridge University Press, 1995.

Andrews, David. "Art Cinema as Institution, Redux: Art Houses, Film Festivals, and Film Studies." Scope: An Online Journal of Film \& TV Studies 18 (2010). http://www.scope.nottingham.ac.uk/article.php?issue=18\&id=1245

Asch, Mark. "New York Film Festival Lineup Announced." The L Magazine, August 17, 2011, http://www.thelmagazine.com/TheMeasure/archives/2011/08/17/new-york-film-festivallineup-announced.

Bell, Christopher. "NYFF '11 Review: Béla Tarr's Swansong 'The Turin Horse' is Despairing But Unforgettable." The Playlist, October 9, 2011, http://blogs.indiewire.com/theplaylist/ nyff_review_bela_tarrs_swan_song_the_turin_horse_is_despairing_but_unforget.

Bell, Robert. "Uncle Boonmee Who Can Recall His Past Lives." Exclaim, accessed April 30, 2010, http://exclaim.ca/Reviews/TIFF/Uncle_Boonmee_Who_ Can_Recall_His_Past_Lives_Directed_by_Apichatpong_Weerasethakul.

Coldiron, Phil. "NYFF '11 Review: Tarr's Final Testament." Fandor Keyframe, October 11, 2011, http://www.fandor.com/blog/nyff-11-review-fade-to-black-the-turin-horse/.

Cutler, Aaron. "New York Film Festival 2010: Preview." The House Next Door, September 16, 2010, http://www.slantmagazine.com/house/2010/09/new-york-film-festival-2010 preview/.

—_. "New York Film Festival 2010: Uncle Boonmee Who Can Recall His Past Lives." The House Next Door, September 23, 2010. http://www.slantmagazine.com/house/2010/ 09/new-york-film-festival-2010-uncle-boonmee-who-can-recall-his-past-lives/\#more17396.

Czach, Liz. "Cinephilia, Stars, and Film Festivals." Cinema Journal 49, no. 2 (Winter 2010): 139-145.

_. "Film Festivals, Programming, and the Building of a National Cinema." The Moving Image 4, no. 1 (Spring 2004): 76-88.

Elsaesser, Thomas. "Film Festival Networks: The New Topographies of Cinema in Europe." Chap. 2 in European Cinema Face to Face with Hollywood. Amsterdam: Amsterdam University Press, 2005.

Evans, Owen. "Border Exchanges: The Role of the European Film Festival." Journal of Contemporary European Studies 15, no. 1 (2007): 23-33.

Dargis, Manohla. "Cult Hits, Carnage, and Even Chaplin." The New York Times, September 29, 2011, http://www.nytimes.com/2011/09/30/movies/new-york-film-festival-now-biggerbeckons.html

Dayan, Daniel. "Looking for Sundance: The Social Construction of a Film Festival." In Moving Images, Culture and the Mind, edited by Ib Bondebjerg, 43-52. Luton: University of Luton Press, 2000.

De Valck, Marijke. Film Festivals: From European Geopolitics to Global Cinephilia. Amsterdam: Amsterdam University Press, 2007. and Mimi Soeteman. “'And the Winner is...': What Happens Behind the Scenes of Film Festival Competitions.” International Journal of Cultural Studies 13 (2010): 290-307. 
Farahmand, Azadeh. "Disentangling the International Festival Circuit: Genre and Iranian Cinema." Chap. 15 in Global Art Cinema: New Theories and Histories, edited by Rosalind Galt and Karl Schoonover, 263-281. Oxford: Oxford University Press, 2010.

Gerhards, Jürgen and Mike S. Schäfer. "Is the internet a better public sphere? Comparing old and new media in the USA and Germany." New Media and Society 12, no. 1 (2010): 143-160.

Gonzalez, Ed. "Uncle Boonmee Who Can Recall His Past Lives." Slant Magazine, September 21, 2010, http://www.slantmagazine.com/film/review/uncle-boonmee-who-can-recallhis-past-lives/5031.

Guillen, Michael. “TIFF 2011: The Turin Horse.” Twitch Film, September 13, 2011, http://twitchfilm.com/reviews/2011/09/tiff-2011-the-turin-horse.php.

Hall, Tom. "Beasts of Burden: Béla Tarr's The Turin Horse." Indiewire, October 5, 2011, http://blogs.indiewire.com/twhalliii/the_2011_new_york_film_festival_beasts_of_burden the turin horse.

Hamid, Rahul. "From Urban Bohemia to Urban Glamour: The Establishment and Early Years of the New York Film Festival." Chap. 9 in Film Festival Yearbook 1, edited by Dina Iordanova and Ragan Rhyne 67-81. St. Andrews: St. Andrews Film Studies, 2009.

Hansen, Miriam. Babel and Babylon: Spectatorship in American Silent Film. Cambridge, MA: Harvard University Press, 1994.

Harbord, Janet. "Film Festivals: Media Events and Spaces of Flow." Chap. 3 in Film Cultures, 59-75. London: Sage, 2002.

Humphreys, David. “TIFF Day 6 and Day 7.” In Movies, September 17, 2010, $\mathrm{http} / / /$ blog.inmovies.ca/2010/09/tiff-day-6-and-day-7-uncle-boonmee-trust-supernorwegian-wood-tabloid.html.

Iordanova, Dina. "The Film Festival Circuit." Chap. 2 in Film Festival Yearbook 1: The Festival Circuit, edited by Dina Iordanova and Ragan Rhyne, 23-39. St. Andrews: St.

Andrews Film Studies, 2009.

Kenigsberg, Ben. "Toronto International Film Festival 2011: Anonymous, The Turin Horse, The Deep Blue Sea." Time Out Chicago, September 16, 2011, http://timeoutchicago.com/artsculture/film/14947303/toronto-international-film-festival-2011-anonymous-the-turinhorse-the-de.

Koresky, Michael. "Jungle Fever.” Reverse Shot 28, accessed April 30, 2010, http://www.reverseshot.com/article/uncle_boonmee_who_can_recall_his_past_lives.

Knegt, Peter. "TIFF List 2010: The Complete Toronto Film Festival Lineup." Indiewire, September 9, 2010, http://www.indiewire.com/article/tiff_list_2010_tracking_torontos_ announced lineup/.

Knight, Chris. "TIFF Mini Reviews: Tender Son, Uncle Boonmee Who Can Recall His Past Lives." National Post, September 14, 2010, http://arts.nationalpost.com/2010/09/14/tiffmini-reviews-tender-son-uncle-boonmee-who-can-recall-his-past-lives/.

Lee, Amy. "Béla Tarr on 'The Turin Horse': The Hungarian Director Discusses His Last Film." The Huffington Post, February 10, 2012, http://www.huffingtonpost.com/2012/ 02/10/bela-tarr-the-turin-horse n 1266397.html.

Lerner, Sarah. "NYFF 2011: The Turin Horse.” The L Magazine, October 12, 2011, http://www.thelmagazine.com/TheMeasure/archives/2011/10/12/nyff-2011-the-turinhorse.

Levy, Shawn. "PIFF34: Week One Reviews." Oregonian, February 10, 2011, http://blog.oregonlive.com/madaboutmovies/2011/02/piff34_week_one_reviews.html. 
__. "Portland International Film Festival Reviews." The Oregonian, February 16, 2012, http://blog.oregonlive.com/madaboutmovies/2012/02/portland_international_film_fe _ 3.html.

Lim, Dennis. "Somber Themes Dominate Berlinale." The New York Times, February 16, 2011, http://www.nytimes.com/2011/02/17/arts/17iht-berfest17.html?_r=1.

Lutkehaus, Nancy C. "The Sundance Film Festival, January 19-29, 1995: Preliminary Notes Toward an Ethnography of a Film Festival." Visual Anthropology Review 11, no. 2 (Fall 1995): 121-129.

Macnab, Geoffrey. "Béla Tarr Flies Hungarian Flag." Screen Daily, February 10, 2012, http://www.screendaily.com/news/europe/bela-tarr-flies-hungarian-flag/5037722.article\#.

Mazdon, Lucy. “Transnational 'French' Cinema: The Cannes Film Festival.” Modern \& Contemporary France 15, no. 1 (February 2007): 9-20.

Mesh, Aaron. "Licking PIFF." The Willamette Week, February 15, 2012, http://wweek.com/ Portland/article-18818-licking_piff.html.

Murray, Noel and Scott Tobias. "TIFF '10: Day 6.” A.V. Club, September 15, 2010, http://www.avclub.com/articles/tiff-10-day-6,45189/.

"New York Film Festival 2010: A Guide to All the Films," IndieWire, accessed April 30, 2010, http://www.indiewire.com/article/guide_new_york_film_festival.

Nichols, Bill. "Discovering Form, Inferring Meaning: New Cinemas and the Film Festival Circuit." Film Quarterly 47, no. 3 (1994): 16-30.

O’Hehir, Andrew. "Cannes Shocker: 'Uncle Boonmee' Wins.” Salon, May 23, 2010, http://www.salon.com/2010/05/23/palme_dor_cannes/.

Peranson, Mark. "First You Get the Power, Then You Get the Money: Two Models of Film Festivals." Chap. 3 in Dekalog 3: On Film Festivals, edited by Richard Porton, 23-37. London: Wallflower, 2009.

Rapold, Nicolas. "In Auteur's Swan Song, an Ode to Survival," The New York Times, February 3, 2012, http://www.nytimes.com/2012/02/05/movies/bela-tarr-says-the-turin-horse-ishis-last-movie.html.

Ran, Ma. "Rethinking Festival Film: Urban Generation Chinese Cinema on the Film Festival Circuit." Chap. 8 in Film Festival Yearbook 1: The Festival Circuit, edited by Dina Iordanova and Ragan Rhyne, 116-135. St. Andrews: St. Andrews Film Studies, 2009.

Reardon, Kiva. “TIFF Review Roundup: September 18." Torontoist, September 18, 2011, http://torontoist.com/2011/09/tiff-review-roundup-september-18/.

Rhyne, Ragan. "Film Festival Circuits and Stakeholders." Chap. 1 in Film Festival Yearbook 1: The Festival Circuit, edited by Dina Iordanova and Ragan Rhyne, 9-22. St. Andrews: St. Andrews Film Studies, 2009.

Rich, Jamie S. "Film Shorts." Portland Mercury, February 10, 2011, http://www.portlandmercury.com/ portland/film-shorts/Content?oid=3350737.

Rosenbaum, Jonathan. "Film Writing on the Web: Some Personal Reflections." Film Quarterly 60, no. 3 (Spring 2007): 76-80.

Roxborough, Scott. “Strand Picks Up 'Uncle Boonmee' for U.S.” The Hollywood Reporter, July 6, 2010, http://www.hollywoodreporter.com/news/strand-picks-uncle-boonmee-us25240.

Schenker, Andrew. "The Turin Horse." The House Next Door, September 27, 2011, http://www.slantmagazine.com/film/review/the-turin-horse/5789. 
Scott, A.O. "A Farewell to This Life, and All Its Ghosts." New York Times, March 2, 2011, http://movies.nytimes.com/2011/03/02/movies/02uncle.html.

Semley, John. "The Turin Horse.” Torontoist, September 8, 2011, http://torontoist.com/2011/ 09/the-turin-horse/.

__. "Uncle Boonmee Who Can Recall His Past Lives." Torontoist, September 8, 2010, http://torontoist.com/2010/09/uncle boonmee who can recall his past lives/.

Sklar, Robert. "Beyond Hoopla: The Cannes Film Festival and Cultural Significance." Cineaste 22, no. 3 (December 1996): 18-20.

Staiger, Janet. "The Politics of Film Canons." Cinema Journal 24, no. 3 (Spring 1985), 4-23.

Stamm, Chris. "PIFF Rolls East." Willamette Week, February 16, 2011, http://wweek.com/ portland/article-16970-piff_rolls_east.html.

Stringer, Julian. "Global Cities and the International Film Festival Economy." Chap. 11 in Cinema and the City: Film and Urban Societies in a Global Context, edited by Mark Shiel and Tony Fitzmaurice, 134-144. Oxford: Blackwell, 2001.

Sweeney, R. Emmett. "The $48^{\text {th }}$ New York Film Festival, Part 2." Movie Morlocks, September 28, 2010, http://moviemorlocks.com/2010/09/28/the-48th-new-york-film-festival-part-2/.

“TIFF Programmes," Toronto International Film Festival, accessed April 30, 2012, http://tiff.net/thefestival/filmprogramming/programmes.

Tully, Michael. "Must-Sees at the New York Film Festival." Hammer to Nail, September 24, 2010, http://www.hammertonail.com/film-festivals/2010-new-york-film-festival-mustsees/.

Wilner, Norm. "Uncle Boonmee Who Can Recall His Past Lives." Now Toronto, accessed April 30, 2012, http://www.nowtoronto.com/guides/tiff/2010/listing.cfm?listingid=627.

Wollen, Peter. "The Canon." Chap. 15 in Paris Hollywood: Writings on Film, 216-232. London: Verso, 2002.

Wong, Cindy Hing-Yuk. Film Festivals: Culture, People, and Power on the Global Screen. New Brunswick, NJ: Rutgers University Press, 2011. 